\title{
Secondary minerals from salt caves in the Atacama Desert (Chile): a hyperarid and hypersaline environment with potential analogies to the Martian subsurface
}

\author{
Jo De Waele ${ }^{1 *}$, Cristina Carbone ${ }^{2}$, Laura Sanna ${ }^{3}$, Marco Vattano $^{4}$, Ermanno Galli ${ }^{5}$, \\ Francesco Sauro ${ }^{1}$, and Paolo Forti ${ }^{1}$ \\ ${ }^{1}$ BiGeA, Dipartimento di Scienze Biologiche, Geologiche e Ambientali, Alma Mater Studiorum - University of Bologna, Via Zamboni 67, 40126 Bologna, Italy \\ ${ }^{2}$ DISTAV, Dipartimento di Scienze della Terra, dell'Ambiente e della Vita, University of Genoa, Corso Europa 26,16132 Genova, Italy \\ ${ }^{3}$ IBIMET, Institute for Biometeorology, National Research Council of Italy, Traversa La Crucca 3, 07100 Sassari, Italy \\ ${ }^{4}$ Dipartimento di Scienze della Terra e del Mare, University of Palermo, Via Archirafi 22, 90123 Palermo, Italy \\ ${ }^{5}$ Dipartimento di Scienze Chimiche e Geologiche - University of Modena and Reggio Emilia, Largo S.Eufemia 19, 41121 Modena, Italy
}

\begin{abstract}
Over the past 15 years several expeditions by French, American and especially Italian cavers have unveiled over 50 caves in the Cordillera de la Sal (Atacama Desert, Northern Chile). Many of these caves contain a variety of speleothems and minerals, some of which have rarely been observed within karst systems. Most of the secondary deposits in these caves are composed of halite, but also other halide, carbonate, sulphate, nitrate, phosphate, and silicate minerals have been found. Among the sixteen cave mineral species recognized, atacamite, darapskite, blödite, leonite, anhydrite, and especially antarcticite are worth mentioning. In one of the samples an unknown Ca-Sr-bearing chloride mineral has also been discovered, but it has not been possible to carry out detailed mineralogical analyses. These often-rare minerals have formed in this region due to the very extreme hyperarid and salt-rich environment. This research reports the mineralogical results and proposes the genetical mechanisms leading to the formation of antarcticite, powdery anhydrite, and the paragenesis of the halite-darapskiteblödite. This study also shows that Atacama caves may be excellent analogues to study weathering processes and subsurface secondary minerals in hyperarid and hypersaline environments on Mars.
\end{abstract}

Keywords: $\quad$ cave minerals, salt caves, hyperaridity, minerogenesis, Mars analogues

Received 18 November 2016; Revised 23 January 2017; Accepted 23 January 2017

Citation: De Waele J., Carbone C., Sanna L., Vattano M., Galli E., Sauro F. and Forti P., 2017. Secondary minerals from salt caves in the Atacama Desert (Chile): a hyperarid and hypersaline environment with potential analogies to the Martian subsurface. International Journal of Speleology, 46 (1), 51-66. Tampa, FL (USA) ISSN 0392-6672 https://doi.org/10.5038/1827-806X.46.1.2094

\section{INTRODUCTION}

Salt caves have been described in only a few regions worldwide, including the Dead Sea (Frumkin et al., 1991; Frumkin, 1994, 1998, Frumkin \& Ford, 1995), the Zagros Mountains in Iran (Bosák et al., 1999; Bruthans et al., 2008, 2009, 2010; Filippi et al., 2011), and the Atacama Desert (Salomon, 1995; Sesiano, 2009). These desert areas are typically characterized by an extremely arid climate, with rainfall usually well below $200 \mathrm{~mm} \mathrm{a}^{-1}$ and often concentrated in short periods of time. Among hypersaline desert areas the central Atacama is the driest one, with mean annual rainfall below $25 \mathrm{~mm} \mathrm{a}^{-1}$, and often with several consecutive years without any rainfall (Houston \& Hartley, 2003; Sesiano, 2006). The geological history and soil mineralogy data of the Atacama region suggest that extreme arid conditions have persisted for 10-15 million years (Ericksen, 1983; Alpers \& Brimhall, 1988; Sillitoe \& McKee, 1996; Hartley et al., 2005; Clarke, 2006), which makes it possibly the oldest desert on Earth.

Despite this extreme hyperarid climate, there are several solution caves in the Oligocene-Miocene evaporites of the Cordillera de la Sal. Cave exploration in this area started only in the early 1990s (Salomon, 1995) and up to now almost 50 caves have been discovered, explored and surveyed for a total development of over $15 \mathrm{~km}$ (Fryer, 1995; Sesiano, 1998, 2006, 2007, 2009; Padovan, 2015). These caves and the evaporite karst area have been the subjects of scientific research only recently (De Waele et al., 2009a, 2009b, 2009c, 2009d; De Waele \& Forti, 2010).

For these peculiar environmental conditions, the Atacama Desert has been proposed as one of the most promising analogues for the chloride-bearing 
evaporative deposits that have been found on the planet Mars (Bobst et al., 2001; Lowenstein et al., 2003). Peculiar hygroscopic minerals and perchlorates have long been postulated and finally found by Phoenix lander on Mars (Clark, 1978; Hecht et al., 2009). Several studies have demonstrated the importance of hygroscopic salts for the potential search of life on the red planet (Davila et al., 2016), also using analogue geomicrobiological studies from the Atacama Desert (Wierzchos et al., 2006; Davila et al., 2013). Solutional caves have also been postulated on Mars in several evaporitic environments (Baioni \& Tramontana, 2015, 2016), thus the study of cave minerals in the Atacama desert could open new research fields on the expected secondary minerals present in the planet's subsurface and their potential as astrobiological targets.

Cave minerals are the results of complex interactions between bedrock, circulating water, and sediments of various sources. Before this study, salt caves on Earth were expected to be generally very poor in secondary minerals, with most speleothems and secondary deposits composed of halite. In the early studies in Mount Sedom salt karst area (Israel) only five minerals have been identified (besides halite, also carnallite, sylvite, gypsum, and anhydrite), together with some unidentified iron oxides and hydroxides (Forti \& Buzio, 1985; Frumkin \& Forti, 1997; Hill \& Forti, 1997). Among them, carnallite would be related to a Dead Sea flood event, so cannot be regarded as a true cave mineral.

Eight cave minerals of Atacama were described earlier based on samples taken in some of the first explored caves (De Waele et al., 2009a), but a new sampling campaign in November 2015 allowed to investigate newly discovered caves on the higher part of the Cordillera (Padovan, 2015). In this paper we describe the sixteen known cave minerals from the Atacama region and the very special conditions that allowed for their formation in this environment. Finally the potential of these caves as analogues for hypersaline subsurface environments on Mars is discussed.

\section{STUDY AREA}

\section{Location and climate}

The Cordillera de la Sal is situated in the Pre-Andean depression near the San Pedro de Atacama village $(2,446 \mathrm{~m}$ a.s.1.) at about $150 \mathrm{~km}$ northeast from the Pacific coast of South America (Fig. 1).

From a general climatic point of view evaporation greatly exceeds precipitation in the Atacama Desert, with temperature of $35^{\circ} \mathrm{C}$ in summer and $5^{\circ} \mathrm{C}$ in winter (mean $14{ }^{\circ} \mathrm{C}$ ), an average relative humidity of $40.5 \%$ (minimum $16.7 \%$, maximum $80.9 \%$ ), rainfall of 25-50 $\mathrm{mm} \mathrm{a}^{-1}$, and evaporation of 1,800-3,200 $\mathrm{mm} \mathrm{a}^{-1}$ (Boschetti et al., 2007). This extreme aridity is produced by the constant regime of the Pacific Anticyclone, a cold current along the west coast of South America, and the rain shadow effect from the Andean Cordillera to the east that produces rare precipitation events, a lack of fog, and the absence of dewfall. Data obtained from the weather station in San Pedro de Atacama during 2011 confirms that moisture is only detected

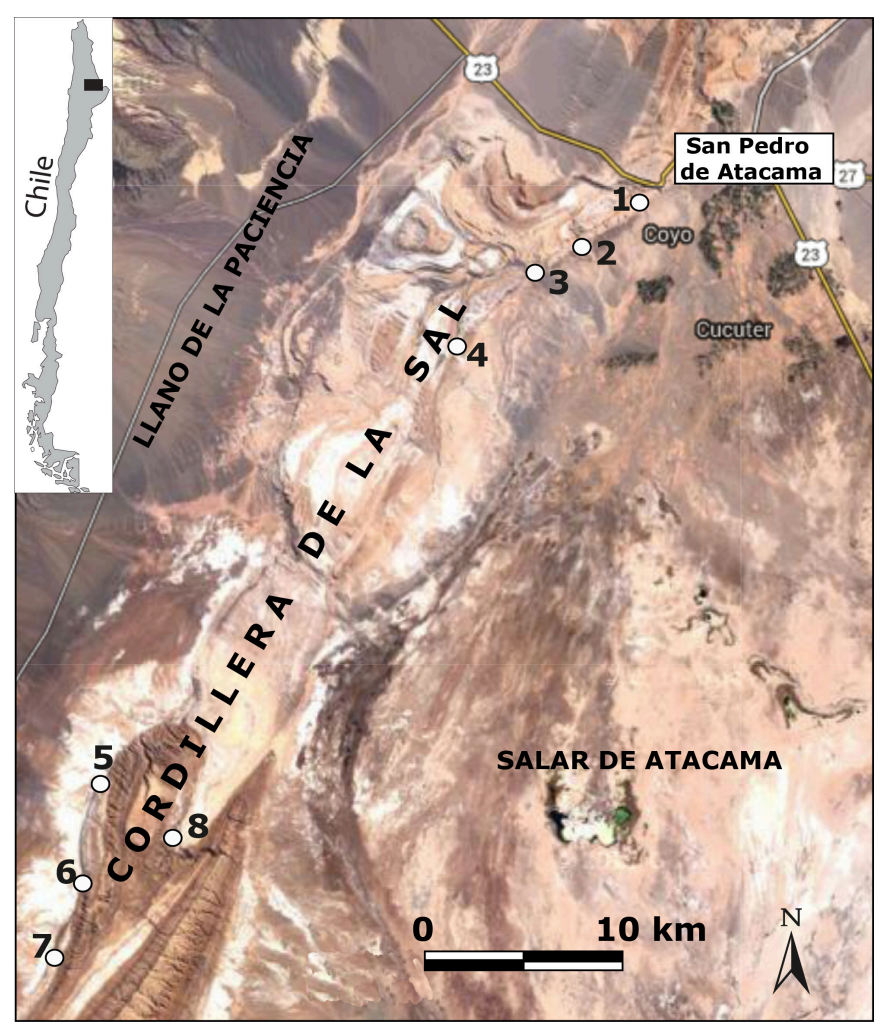

Fig. 1. The Cordillera de la Sal anticline and the investigated caves: 1) Chulacao Cave; 2) Lechuza del Campanario Cave; 3) Parede de Vidrios Cave; 4) Zorro Andina Cave; 5) Vicuña Seca Cave; 6) Arco de la Paciencia Cave; 7) Ventanas Cave; 8) Cressi cave system. Image from Google Earth.

on rock surfaces during rainfalls and for a short time after a rain event (DiRuggiero et al., 2013). Historical rainfall records show that the most extreme localized rain events are generally related to El Niño years, while La Niña brings a greater regional annual precipitation (Ortlieb, 1994; Morales et al., 2012). Water recharge in the area is mainly guaranteed from the Altiplano, through the Rio San Pedro stream that cuts the Cordillera de la Sal anticline in its northern part. This valley allows for the observation of the internal structure of this Oligocene-Miocene anticline.

\section{Geology}

From a geological point of view the Cordillera is composed of an over 1,800-m thick sequence of Tertiary continental sediments of the Paciencia Group, a package of alluvial conglomerates that interfinger with the San Pedro Formation, this last being a series of fine-grained clastic sediments including some 20 to 60 $m$ thick interbedded salt units (Wilkes \& Görler, 1994). The chlorides derive from the recycling enrichment of marginal marine deposits such as paralic clastics, limestones, and abundant evaporites (gypsum and halite) deposited from Cretaceous to Paleogene in the Salar of Atacama, which was an interior seaway at that time (Mpodozis et al., 2005). This basin has been closed and filled with clastic sediments since the Eocene, when the mountain chain started its uplifting (Dunai et al., 2005). During the Early to Mid-Miocene, the Paciencia Group started to deform into a series of salt folds along the axis of the present day Cordillera de la Sal. The Artola Ignimbrite (Vilama Group) overlies the folded Paciencia Group, thus dating the regional unconformity to $9.40 \mathrm{Ma}$ (Evenstar et al., 2016). The 
salt rock does not show clear evidence of diapirism, and does not display primary features such as crude bedding, laminations, lateral and vertical facies grading to clastics, and never exhibits the piercing of younger strata (Arriagada et al., 2006).

\section{Caves}

The caves are all located in the Cordillera de la Sal, a NE-SW elongated fold- and thrust belt a couple of kilometres wide and over $100 \mathrm{~km}$ long. This ridge is bounded to the east by the Salar de Atacama, bordered by the Salar Fault system at the foot of the Western Cordillera de los Andes (Altiplano), and to the west by the narrow Llano de la Paciencia at the margin of the Domeyko Range in the Precordillera. More than 50 caves are known in the Cordillera de la Sal, several of which are over $2 \mathrm{~km}$ long. The most important ones are "through caves" accessible from the sinking stream down to the resurgence. They often start with collapses that allow access to the below lying dry-cave riverbed. Once this floor is reached the caves are often easily traversed downstream (and upstream) until they lead to an open sky canyon. These skylights can be short, thus representing cave entrances (shafts), but can also be relatively long, thus dividing different parts of a single cave system. The underground passages are typically characterized by meandering behaviour with a cave floor very close to the horizontal. The long profile in fact often shows a gradient of less than $3 \%$. In cross section the cave passages can be described as composed of stacked conduits with different sizes, probably deriving from different climate regimes in the past. The walls of a single conduit also show horizontal notches, demonstrating these conduits to have grown in response to a series of flood pulses, each of them having dissolved a part of the salt floor. Some of these older cave conduits still contain diamictons (debris flow sediments), deposited by a last major flood pulse. Dating of bones contained within these terrigenous infillings indicates that these caves formed in the last $6 \mathrm{ka}$ (De Waele et al., 2009d).

Cave microclimate conditions are characterised by in-cave temperatures ranging between 15 and $18^{\circ} \mathrm{C}$, depending on altitude, cave depth below the surface, and size/number of their openings. Cave relative humidity is always very low (around 15\%) enforced by the constant airflow through the entire cave length. The long periods of extreme dryness favour evaporation on cave walls, except during rare rain events. Sometimes decades can pass between one rain event and another.

Secondary minerals and speleothems have been sampled in eight caves, four of them visited in 2009, and the remaining four during the 2015 expedition (Fig. 1). On the east side of the Cordillera de la Sal, Mina de Chulacao Cave is a $1 \mathrm{~km}$ long giant salt cave passage, among the biggest and probably the oldest in the area. It is also the closest to the San Pedro de Atacama village (around $4 \mathrm{~km}$ west of the village). The canyon-like passage reaches a height of over 20 $\mathrm{m}$, and width of $25 \mathrm{~m}$ (Fryer, 2005). The downstream entrance area has been used for the exploitation of copper minerals, of which remains are still clearly visible. Lechuza de Campanario Cave is located $3 \mathrm{~km}$ southwest of Chulacao Cave, with the downstream entrance on the same flank of the Cordillera de la Sal. Its passages are much smaller than Chulacao's (average width $4 \mathrm{~m}$, highest ceiling $10 \mathrm{~m}$ ), for a development of around $600 \mathrm{~m}$ (Fryer, 2005).

Parede de Vidrios Cave is a frequently visited cave because it is located at the second entrance gate before ascending to the Valle de la Luna Natural Park, in vicinity of a parking lot and a wide canyon floor (1.2 $\mathrm{km}$ southwest from Lechuza Cave). It is a $2-3 \mathrm{~m}$ wide and up to $10 \mathrm{~m}$ high meandering canyon with several skylights. Zorro Andina Cave is located $4 \mathrm{~km}$ further to the southwest, and a long walk is needed to reach this beautiful 300-m long cave. It has a $5 \mathrm{~m}$ wide and up to $7 \mathrm{~m}$ high meandering cave passage, decorated with beautiful halite speleothems.

The biggest cave systems are located on the west side of the Cordillera de la Sal, $35 \mathrm{~km}$ southwest of San Pedro de Atacama. These have been explored in the last few years by Italian cavers (Padovan, 2015). Arco de la Paciencia Cave opens out into the Llano de la Paciencia, and is a $>2 \mathrm{~km}$ long meandering cave passage with a clear upper level rich in halite speleothems. Vicuña Seca Cave, with characteristics similar to Arco de la Paciencia Cave, is located $4 \mathrm{~km}$ north and is around $2 \mathrm{~km}$ long, while Ventanas Cave is found $2 \mathrm{~km}$ south and is only half a $\mathrm{km}$ long. The Cressi cave system, is located on the summit plain of the central core of the Cordillera de la Sal and has several entrances that give access to a canyon with multiple skylights. The total development of the cave trunks exceeds $5 \mathrm{~km}$, making this system the longest cave in Chile, and among the longest halite caves of the world.

\section{Methods}

Secondary minerals sampled for this study include stalactites, flowstones, precipitates that form crusts in the streambeds and at the groundwater seeps, coatings along the cave walls, earthy masses from the cave floors, and efflorescence salts on ceiling rock outcrops. Cave mineral and speleothem samples were collected during two expeditions (2009 and 2015) with a knife or a geological hammer using small plastic containers or sampling bags.

Mineral phases were determined by combining $\mathrm{X}$-ray diffraction data with semi-quantitative chemical analyses. X-ray analyses were performed on a Philips PW 1050/25 diffractometer (Department of Chemical and Geological Sciences, Modena and Reggio Emilia University), or on Gandolfi cameras (Ø $114.6 \mathrm{~mm}$, 24/48 $\mathrm{h}$ standing time) when the material was scarce. In both cases experimental conditions were $40 \mathrm{kV}, 20 \mathrm{~mA}$, filtered CuKa Ni radiation, $\lambda=1.5418$ $\AA$. All the samples, and in particular the fragments used in Gandolfi cameras, were characterised by means of semi-quantitative chemical analyses and high resolution frames from a scanning electron microscope (ESEM Philips XL40) equipped with EDS - EDAX 9900 microprobe (Centro Interdipartimentale Grandi Strumenti - C.I.G.S., Modena and Reggio Emilia University). 
Samples analysed at the DISTAV (Genoa University) used a Philips PW3710 diffractometer (current: $20 \mathrm{~mA}$, voltage: $40 \mathrm{kV}$, range $2 \theta: 5-80^{\circ}$, step size: $0.02^{\circ} 2 \theta$, time per step: $2 \mathrm{sec}$ ) equipped with a Co-anode and interfaced with Philips High Score software package for data acquisition and processing. Scanning electron microprobe analyses were performed with a SEM VEGA3 TESCAN (DISTAV, Genoa University) operated at $20 \mathrm{kV}$ and equipped with the EDAX-APOLLO_X DPP3 energy-dispersive (EDS) X-ray spectrometer equipped with an ultrathin polymer window and with resolutions for Manganese $\mathrm{K} \alpha=126 \mathrm{eV}$ and typically ranging detection for chemical elements of atomic number greater than 5 (Boron). Data acquisition and elaboration were performed with the TEAM Enhanced Version: V4.2.2 EDS software.

\section{Cave minerals}

Mineralogical analyses have revealed a great variety of secondary deposits for the Atacama salt caves. In all, 16 mineral species have been identified (Table 1), six of which are quite rare for cave environments. Most secondary mineral phases are composed of halite but other minerals have been observed occasionally such as other halides, sulphates, phosphates, nitrates, carbonates, and silicates.

Table 1. Cave minerals identified in Atacama caves: Ch - Mina de Chulacao; Lec - Lechuza de Campanario; Pav - Parede de Vidrios; Zra - Zorro Andina; Arc - Arco de la Paciencia; Vs - Vicuña Seca; Vent - Ventanas; Cre - Cressi cave system.

\begin{tabular}{|c|c|c|c|}
\hline Cave & Mineral & Nominal chemical formula & Occurrence \\
\hline All & Halite & $\mathrm{NaCl}$ & $\begin{array}{l}\text { Ubiquitous as speleothem. This mineral is sometimes } \\
\text { present as small euhedral ice-luster millimetric crystals }\end{array}$ \\
\hline Arc & Antarcticite & $\mathrm{CaCl}_{2} \cdot 6 \mathrm{H}_{2} \mathrm{O}$ & $\begin{array}{l}\text { White, ephemerous, millimetre-long curls on clay-marly } \\
\text { substrate }\end{array}$ \\
\hline $\mathrm{Ch}$ & Atacamite & $\mathrm{Cu}_{2} \mathrm{Cl}(\mathrm{OH})_{3}$ & $\begin{array}{l}\text { In globular aggregates of emerald green radial elongated } \\
\text { crystals or, rarely, as millimetric veins of euhedral crystals }\end{array}$ \\
\hline $\mathrm{Ch}$ & Aragonite & $\mathrm{CaCO}_{3}$ & $\begin{array}{l}\text { Crusts up to } 5 \mathrm{~mm} \text { thick of vitreous luster transparent to } \\
\text { pale-blue or light-green tabular prismatic crystals }\end{array}$ \\
\hline $\begin{array}{l}\text { Ch, Zra, } \\
\text { Cre, Arc, } \\
\text { Vent, Vs }\end{array}$ & Anhydrite & $\mathrm{CaSO}_{4}$ & $\begin{array}{l}\text { Small lens-shaped aggregates of milky white fibers over } \\
\text { euhedral partially corroded gypsum crystals, or white } \\
\text { powders filling fractures or solution pockets. }\end{array}$ \\
\hline Zra & Bassanite & $2 \mathrm{CaSO}_{4} \cdot \mathrm{H}_{2} \mathrm{O}$ & $\begin{array}{l}\text { Rare very small fibres inside an earthy material in } \\
\text { corrosion pockets on the surface of gypsum crystals }\end{array}$ \\
\hline All & Gypsum & $\mathrm{CaSO}_{4} \cdot 2 \mathrm{H}_{2} \mathrm{O}$ & $\begin{array}{l}\text { Transparent centimetre-sized, euhedral crystals, partially } \\
\text { transformed into bassanite and anhydrite }\end{array}$ \\
\hline Cre, Arc & Barite & $\mathrm{BaSO}_{4}$ & $\begin{array}{l}\text { Small micrometric inclusions in halite, not visible with } \\
\text { naked eye }\end{array}$ \\
\hline Cre & Celestine & $\mathrm{SrSO}_{4}$ & $\begin{array}{l}\text { Small micrometric prismatic crystals in halite, not visible } \\
\text { with naked eye }\end{array}$ \\
\hline Cre & Blödite & $\mathrm{Na}_{2} \mathrm{Mg}\left(\mathrm{SO}_{4}\right)_{2} \cdot 4 \mathrm{H}_{2} \mathrm{O}$ & $\begin{array}{c}\text { Granular material in the yellowish crusts on dried out } \\
\text { cave pools }\end{array}$ \\
\hline Arc, Cre & Leonite & $\mathrm{K}_{2} \mathrm{SO}_{4} \cdot \mathrm{MgSO}_{4} \cdot 4 \mathrm{H}_{2} \mathrm{O}$ & $\begin{array}{c}\text { Small amounts together with antarcticite, not visible with } \\
\text { naked eye. }\end{array}$ \\
\hline Cre & Darapskite & $\mathrm{Na}_{3}\left(\mathrm{NO}_{3}\right)\left(\mathrm{SO}_{4}\right) \cdot \mathrm{H}_{2} \mathrm{O}$ & $\begin{array}{l}\text { Small submillimetric laminar crystals in yellowish crusts } \\
\text { on dried out cave pools }\end{array}$ \\
\hline Arc & Cl-Apatite & $\mathrm{Ca}_{5}\left(\mathrm{PO}_{4}\right)_{3}[\mathrm{Cl}]$ & Traces in some samples \\
\hline Pav & Biphosphammite & $\left(\mathrm{NH}_{4}, \mathrm{~K}\right) \mathrm{H}_{2} \mathrm{PO}_{4}$ & Thin small pale yellow layered fibres \\
\hline Pav & Guanine & $\mathrm{C}_{5} \mathrm{H}_{3}\left(\mathrm{NH}_{2}\right) \mathrm{N}_{4} \mathrm{O}$ & Earthy, silky-luster milky white to pale pink crusts \\
\hline $\mathrm{Ch}$ & Clinoptilolite & $\mathrm{Na}_{4} \mathrm{~K}_{1.5} \mathrm{Ca}_{0.5}\left(\mathrm{Al}_{6.5} \mathrm{Si}_{29.5} \mathrm{O}_{72}\right) \cdot 20 \mathrm{H}_{2} \mathrm{O}$ & $\begin{array}{l}\text { Small whitish to pale-pink earthy grains with a few } \\
\text { euhedral crystals always strongly associated with halite }\end{array}$ \\
\hline
\end{tabular}

\section{Halides}

In the Atacama salt caves the majority of speleothems are composed primarily of halite, which forms macrocrystalline deposits/speleothems (euhedral crystals and clusters, stalactites, etc.), microcrystalline (or fine-grained) deposits/speleothems (bent stalactites, flowstone, crusts, helictites, etc.), solid deposits/speleothems (glaze crusts, water table films, etc.) (Fig. 2). In general the halite forms of Atacama (De Waele et al., 2009a, 2009c) resemble those of other salt karst areas in the world (Hill \& Forti, 1997; Filippi et al., 2011).

Halite is ubiquitous in all of the caves, but other minerals from the same group have been observed occasionally, such as the very rare cave minerals atacamite and antarcticite, whose occurrence is consistent with the low relative air humidity $(<25 \%)$ in this karst environment (Onac, 1996; Reich, 2008).
Atacamite has been found close to the southern entrance of Mina de Chulacao Cave as rounded aggregates of emerald to dark green crystals and crystalline crusts on the cave walls, associated with small, thin, white to pale-green aragonite crusts.

Antarcticite, a highly hygroscopic mineral, occurs as efflorescences of acicular crystal aggregates (Fig. 3C-D) protruding outward from a marly interbedded layer on the cave walls in the Arco de la Paciencia Cave. This sample also contains traces of barite, anhydrite, $\mathrm{Cl}$-apatite, and the rare $\mathrm{K}-\mathrm{Mg}$ sulphate leonite (Fig. 4). Antarcticite crystallizes close to anhydrite zones (Fig. 3B), as required to create a Ca-enriched saline brine completely depleted in sulphate. Halides precipitate in hot and arid zones when $90 \%$ of salt water is evaporated, so they often occur along with other minerals that are created by evaporation, such as sulphates. 

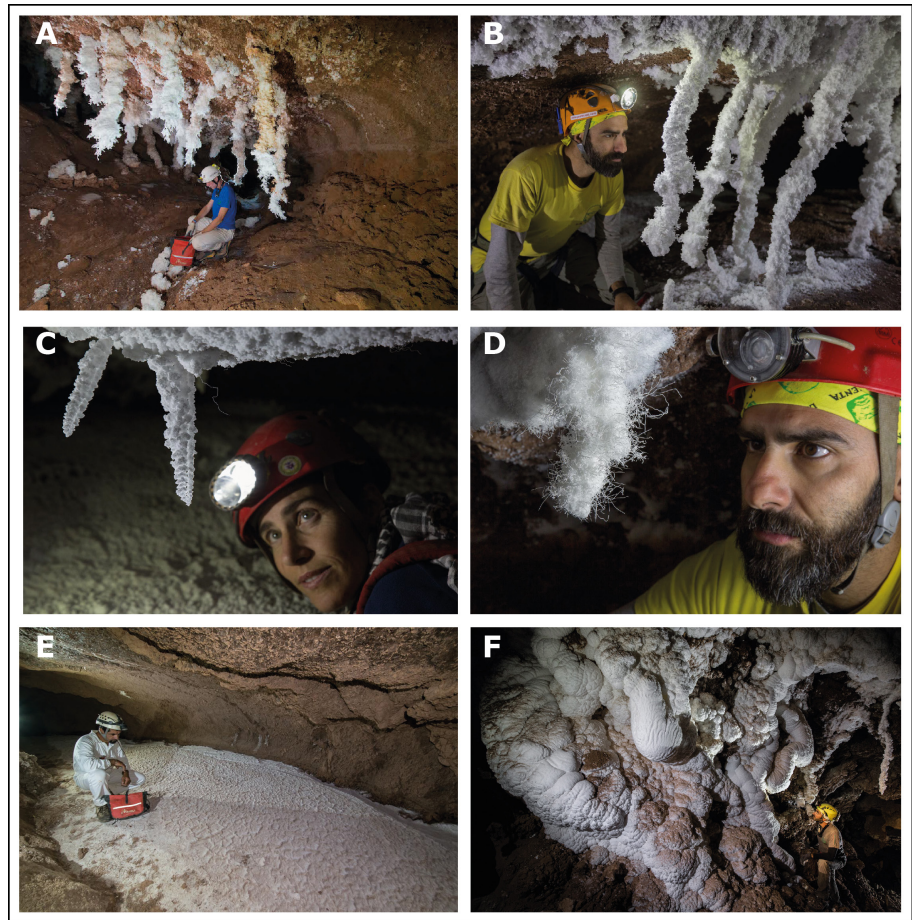

Fig. 2. Typical halite speleothems from the Atacama caves: A) Bent stalactites; B) Bent stalactites forming columns and some small stalagmites; C) Macrocrystalline halite stalactites; D) Cottonballs; E) Salt crust covering the dry riverbed; F) Glaze (toothpaste-like) halite flowstone (A and E: Photos Marco Vattano, La Venta Esplorazioni Geografiche; B, C, D, and F: Photos Riccardo De Luca, La Venta Esplorazioni Geografiche).
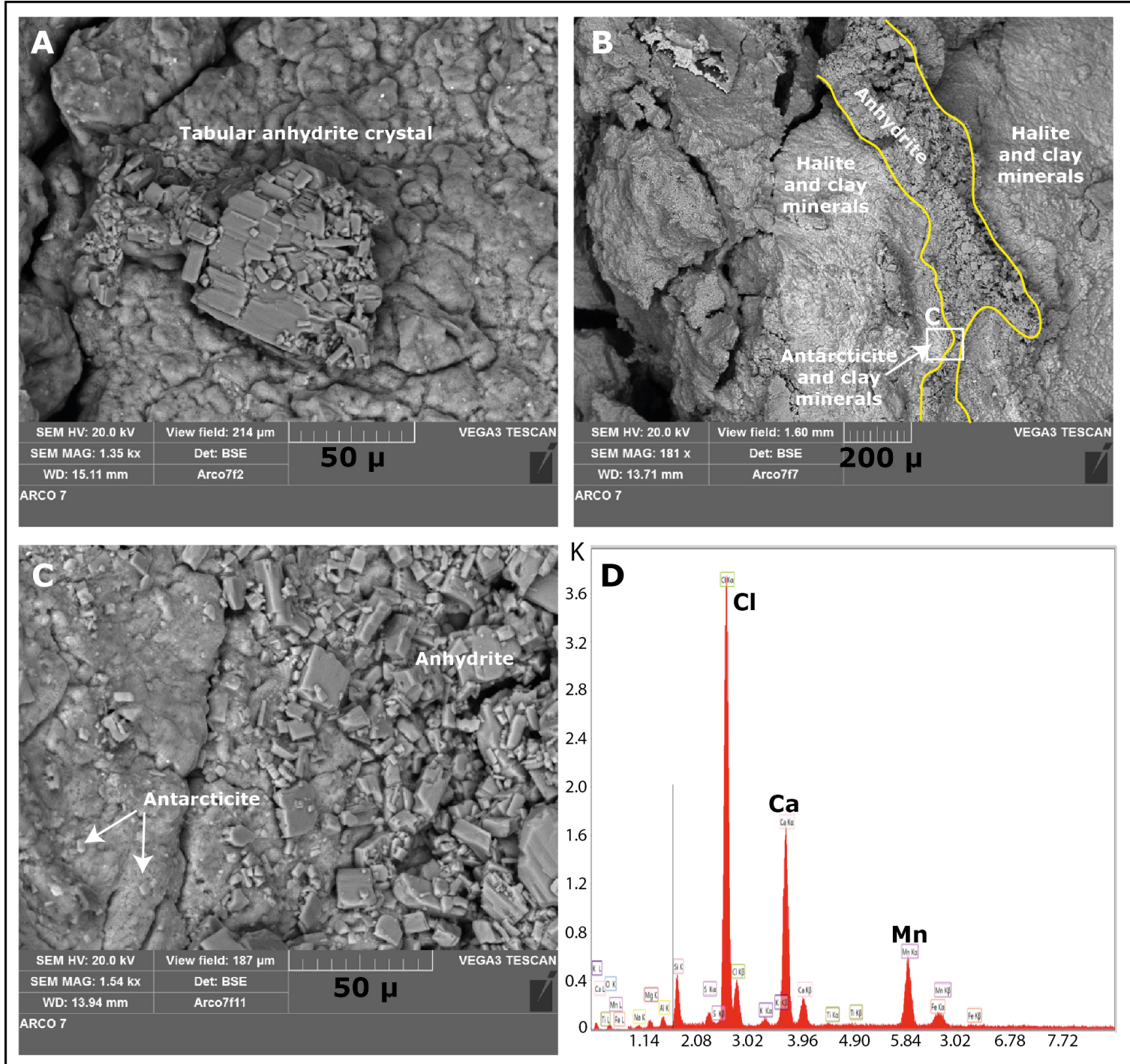

Fig. 3. SEM images of the association antarcticite-anhydrite at Arco de la Paciencia Cave. A) Lamellar anhydrite crystal; B) The tabular to lamellar anhydrite crystals form an elongated area, surrounded by halite, clay minerals, and local patches of antarcticite; C) Detail of the antarcticite crystals (location in B); D) X-ray mapping indicates the presence of $\mathrm{Ca}$ and $\mathrm{Cl}$. Manganese peaks are related to Mn oxides or the clay minerals. 


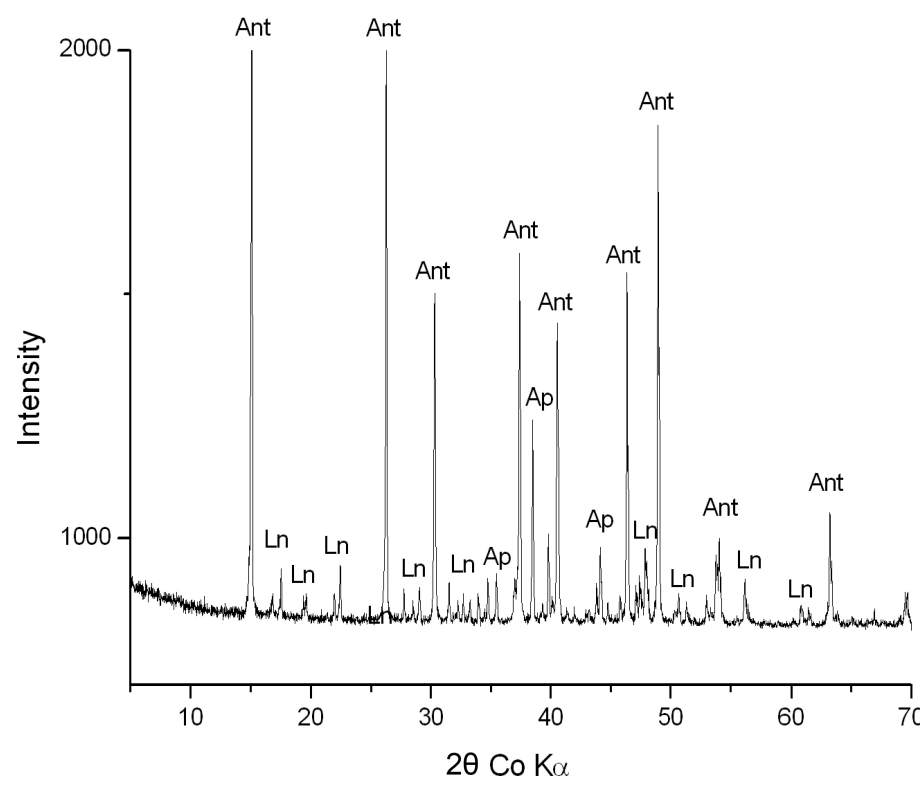

Fig. 4. XRD pattern for the sample from Arco de la Paciencia Cave showing the presence of antarcticite, leonite, and apatite.

\section{Sulphates}

Despite the predominant halite lithology of the Atacama host rock, its caves represent a large variety of sulfate minerals probably derived from minor presence of sulphates in the host rock. Among these secondary phases, gypsum, bassanite, and anhydrite have commonly been found in the caves and at the surface (De Waele \& Forti, 2010). Gypsum occurs close to the opening of Chulacao Cave where it was partially transformed into anhydrite, and in the entrance part of Zorro Andina Cave associated with tabular to lamellar anhydrite and bassanite. Anhydrite forms relatively pure white, fine powders filling fractures and dissolution pockets far from the entrance in the Arco de la Paciencia Cave, close to the base of an internal $25 \mathrm{~m}$ shaft, and in the folded decametric clayey interstratum. Anhydrite has also been sampled in Vicuña Seca and Ventanas caves in similar environmental conditions. This mineral occurs as microscopic tabular and lamellar crystals (Fig. 5A). In many cases the crystals are made of tiny little lamellae (Fig. 5B); otherwise crystals are equant showing large pinacoidal faces (Fig. 5C). Larger anhydrite crystals are often tabular (Fig. 3A and 5A).

Leonite is, together with blödite, a double salt characteristic of marine salt deposits on Earth (Alpers et al., 2000) forming as secondary mineral of metasomatic origin. Its first description as a cave mineral was in Tăuşoare Cave in Romania (Onac et al., 2001) and then in Wooltana Cave in Australia (Snow et al., 2014). In Atacama it occurs together with antarcticite in Arco de la Paciencia
Cave, but also in the yellowish crusts over dry lakes in the Cressi cave system, together with other sulphates (blödite and darapskite), and halite (Fig. 6). Leonite is a sulfate mineral subjected to humidity-related phase transition (deliquescence), so secondary reactions in the salt-clay beds can remove it from the evaporite crusts. In this case, at cave temperatures below $25^{\circ} \mathrm{C}$, the blödite precipitated first with respect to leonite and forms acicular crystals filling voids in the halite mass (Fig. 7A-B).

The leonite-blödite-darapskite paragenesis has also been found in another spot in the Cressi cave system, upstream of the large salt lake; in this case it occurred in association with anhydrite and celestine. Darapskite, on the other hand, forms microcrystalline tabular aggregates covering halite and blödite (Fig. 7C). Point elemental composition analyses have confirmed the presence of these two rare cave minerals (Fig. 7D-E).

As mentioned above, other two sulfate minerals have been recognised in Atacama caves: barite and celestine that occur as micrometric crystals in halite.
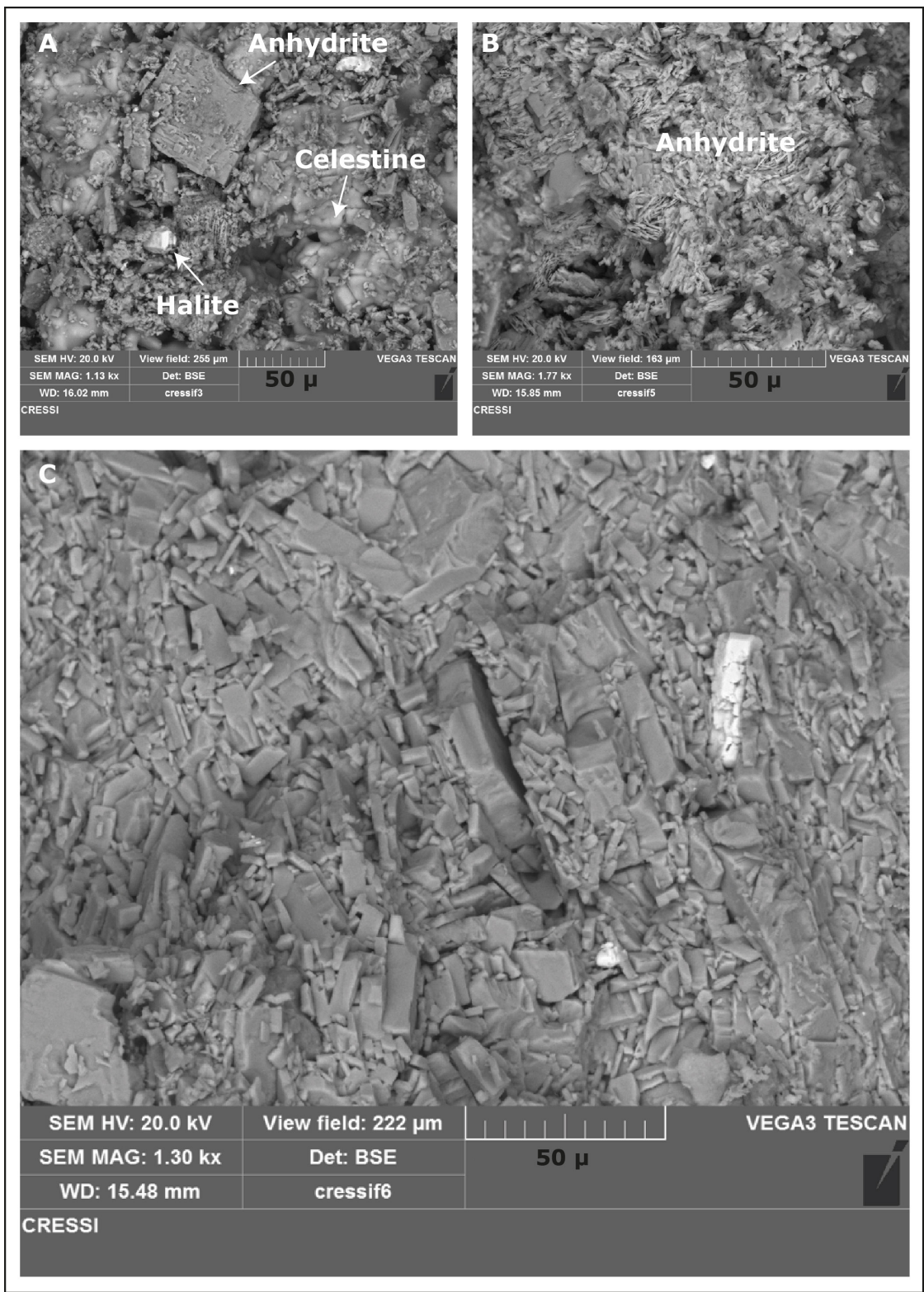

Fig. 5. SEM photographs of anhydrite in vugs of Cressi cave system. A) Anhydrite crystal embedded in halite with some patches of celestine; B) Thin laminae of anhydrite; C) Tabular anhydrite crystals, with a prismatic crystal of celestine (white). 

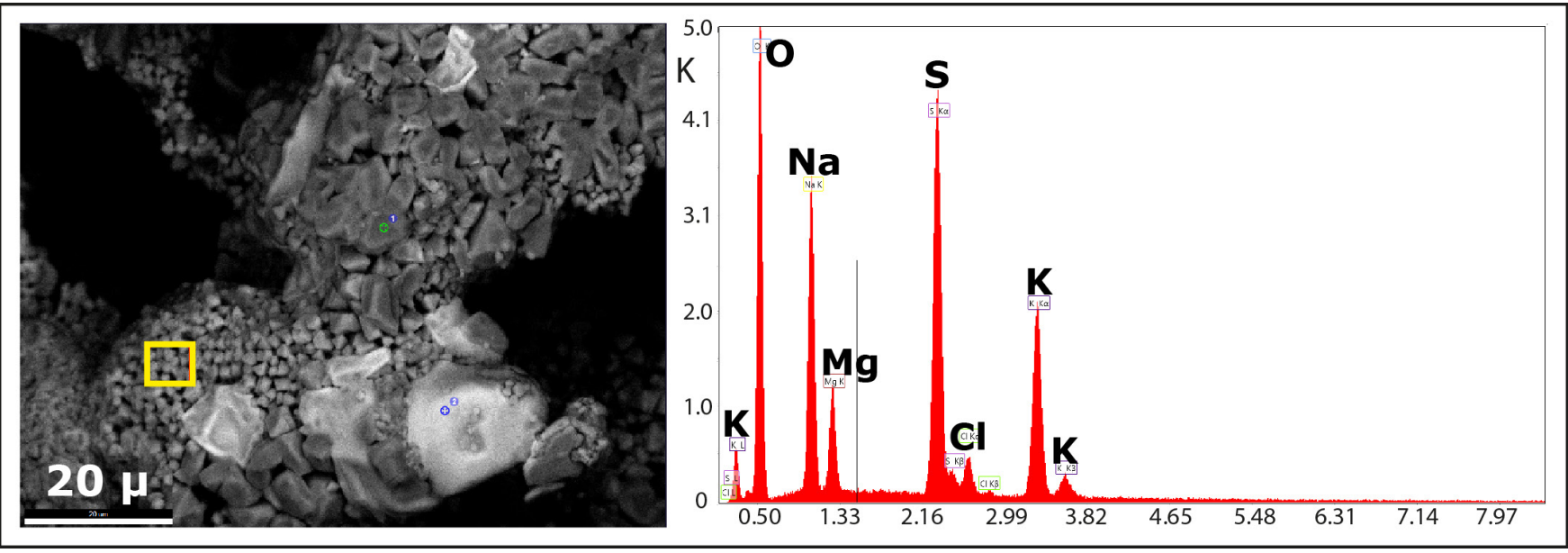

Fig. 6. SEM-EDS analyses for leonite in the Cressi cave system sample (left, yellow rectangle where the EDS analysis has been done) and the elemental composition showing the relative proportion of $\mathrm{K}, \mathrm{Mg}$ and sulphate, together with halite.
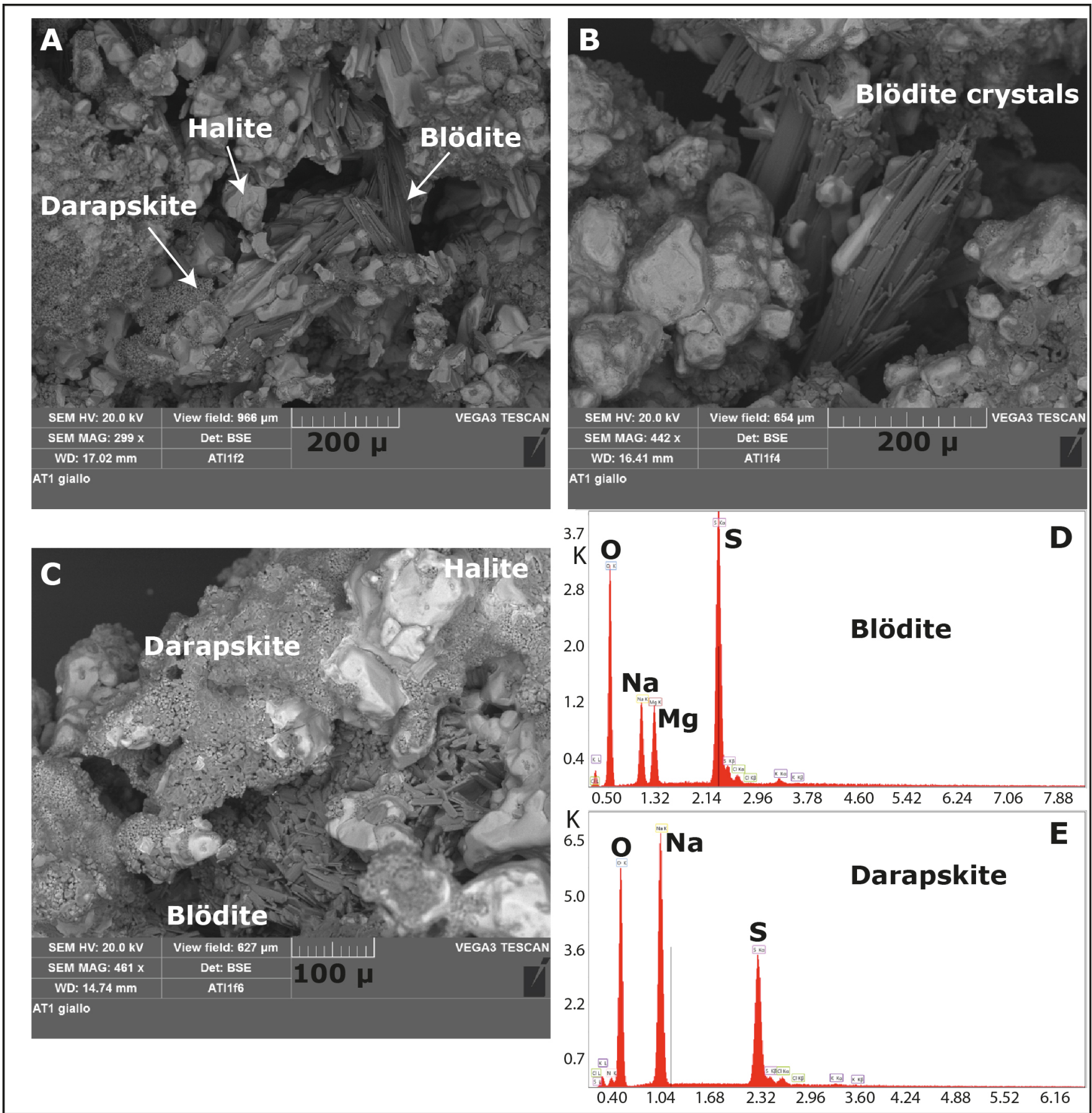

Fig. 7. SEM images of secondary minerals precipitated in the dry lakes of Cressi cave system. A) The occurrence of the minerals halite, darapskite, and blödite; B) Detail of the blödite crystals; C) Detail of the tiny tabular darapskite crystals covering halite. D-E) EDS spectra for the mineral particles show the presence of blödite and darapskite. 
Phosphates and organic minerals

Among the animals frequenting the caves, barn owls are the most common birds. Their droppings and pellets can be seen close to the entrances, and these organic products have sometimes transformed into secondary cave minerals. Biphosphammite and guanine are two of these minerals, detected in the Parede de Vidrios Cave. Biphosphammite has often been found in caves (Hill \& Forti, 1997), related to the liquid phase of guano and/or bird droppings. This very soluble mineral has been preserved in this very dry environment. Guanine, formed during the early stages of the mineralisation of guano and/or bird droppings, is a much rarer cave mineral, reported from desert caves in Chile, Western Australia, and Mexico (Bridge, 1974; Forti et al., 2004). Also the traces of Cl-apatite found in Arco de la Paciencia Cave are probably related to minor amounts of phosphates (bones) brought into the cave.

\section{Silicates}

In a karst pocket close to the entrance of Chulacao Cave, authigenic Na-clinoptilolite has been found, which is a typical zeolite of alkaline saline lakes (Mason \& Sand, 1960; Gottardi \& Galli, 1985; Coombs et al., 1997). Clinoptilolite is probably a more common phase in evaporites, indicting greater aridity and reflecting the high level of $\mathrm{Na}$ in the saline brine.

\section{Other minerals}

One sample in Arco de la Paciencia Cave also contained an unknown mineral phase, perhaps a new mineral, composed of $\mathrm{Sr}, \mathrm{Ca}$, and $\mathrm{Cl}$ (Fig. 8A-C). This unknown mineral phase forms porous aggregates (Fig. 8B) covering compact halite with cubic forms. Unfortunately the amount of material found and its deliquescence has not allowed carrying out more detailed mineralogical investigations.
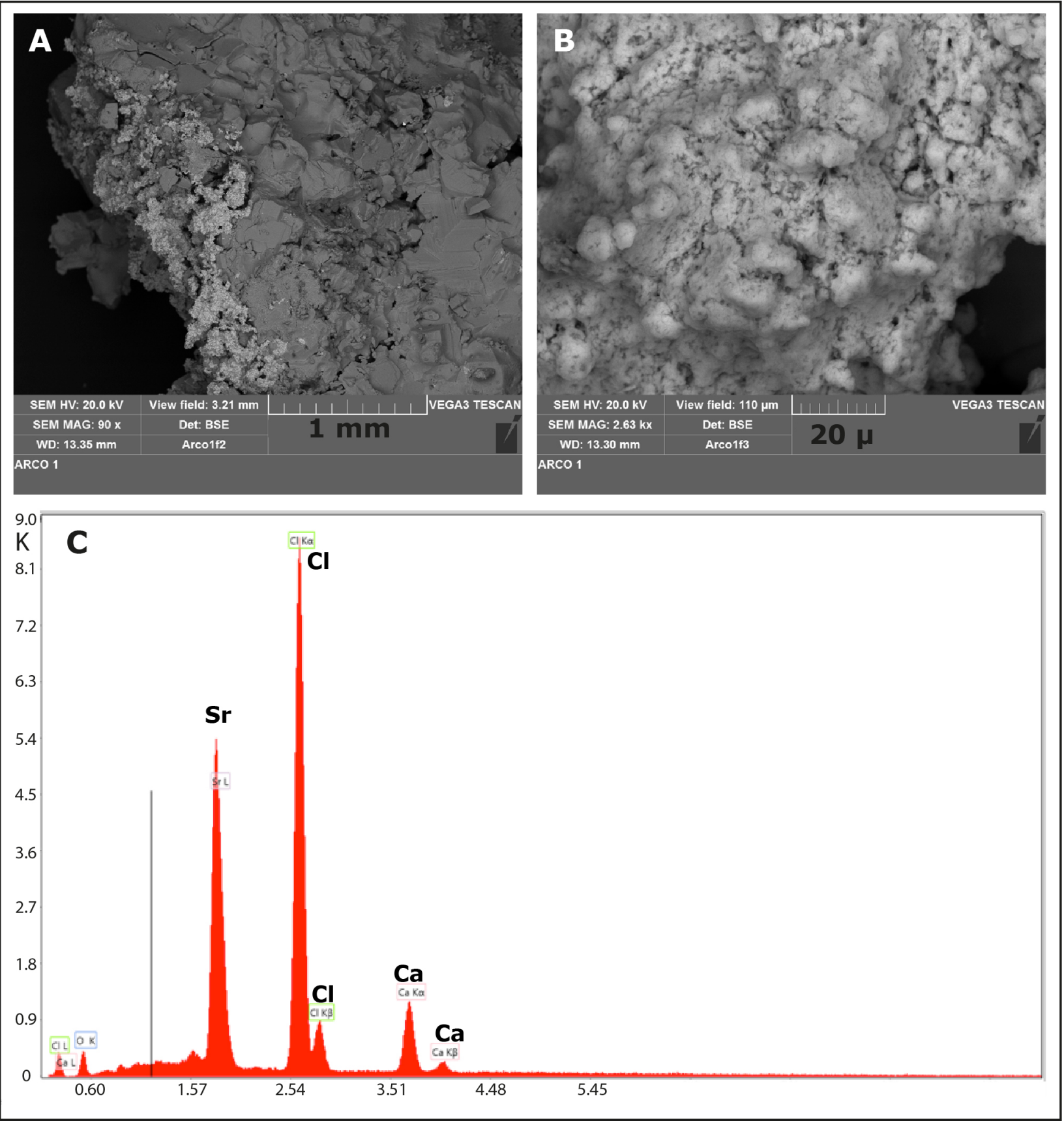

Fig. 8. SEM photographs of the unknown mineral phase in Arco de la Paciencia Cave. A) The porous aggregates of an unknown mineral phase covering halite; B) Detail of the unknown mineral. C) EDS spectrum confirming the presence of the unknown Ca-Sr chloride. 


\section{DISCUSSION}

\section{Environmental conditions}

Most of the secondary minerals found in the salt caves of Atacama are derived from the evaporation of brines (i.e., halite, gypsum, antarcticite, darapskite, blödite, leonite), or from the dehydration of gypsum (bassanite, anhydrite) induced by the hot, arid climate of the area. The high solubility and the ephemeral nature of most of these phases makes them difficult to preserve in most of the common cave conditions around the world, where atmospheres saturated in water vapour react with the previously formed salt minerals, especially with halite whose deliquescence threshold is $75 \%$ of relative humidity at $20^{\circ} \mathrm{C}$ (Filippi et al., 2011).

In the dry conditions of the Cordillera de la Sal, water penetrating the cave's host rock along fractures and bedding planes after sporadic rain events leads to the dissolution of primary minerals and allows the formation of seeping brines with dissolved salts. Moreover, the undersaturated flood water that rarely inundates the cave passages dissolves rocks and crusts, thus becoming brines at or near saturation with respect to halite. Both of these processes selectively add solutes to the incoming rain water, changing its chemistry and producing brines very depleted in carbonate due to the scarce presence of limestone in the area. The evaporation of these saltrich fluids at the cave-atmosphere interface causes secondary minerals such as sulphates and especially halite to precipitate in the form of salt efflorescences and crusts. The specific salts that crystallise at any location within these caves are a function of the local composition of the solution, reflecting dissolved element concentrations, and are controlled by the low relative humidity. In fact, the extremely dry climate of Atacama also permits the preservation of very rare mineral assemblages.

In this dry, evaporative cave environment dominated by chloride and sodium the most common salt is halite. Although smaller in volume, gypsum forms in the initial mixture due to its relatively lower solubility in water compared to other soluble calcium salts and sulfate species. The final brine is rich in sodium, potassium, magnesium, calcium and chloride and the further evaporation leads to an evaporative sequence of sulphates and halides, similar to what happens in a closed basin with very high salinity.

In the element recycling process from the primary minerals, the micrometric crystals of barite and celestine are probably also related to the extreme evaporation of brines in which small amounts of $\mathrm{Ba}^{2+}$ and $\mathrm{Sr}^{2+}$ were present. Barium and strontium are common constituents of sea sediments whose mineralogy is dominated by non-terrigenous sources, so these alkaline metals are likely mobilised from the cave host rock.

On the other hand, aragonite and atacamite were probably deposited by hydrothermal fluids rising along faults visible near the entrance of Chulacao Cave. The copper needed to form atacamite probably derived from these fluids while the halite provided the necessary chloride ions. Also clinoptilolite, found in pockets near the atacamite and aragonite location, is probably related to the reworking of Al-Si rich volcanic minerals present in the area.

Other minerals have formed in this extremely dry environment in the presence of nitrogen and phosphates coming from nitrate ores or likely from bird droppings or guano and their dehydration products (guanine, biphosphammite, and darapskite).

Of all these minerals, five have a genesis that deserves to be explained in more detail: antarcticite, anhydrite, and the paragenesis blödite, leonite, and darapskite.

\section{Origin of the most interesting minerals}

\section{Antarcticite}

This mineral, the only one taking its name from a continent, has been reported in only a few places on Earth as a discrete mineral (it is also found in fluid inclusions). It was first discovered in a playa lake in the Mojave Desert, in California (Dunning \& Cooper, 1969), although its earliest description and publication is due to Torii \& Ossaka (1965) based on the finding of prismatic crystals in a hypersaline lake in Antarctica. Another occurrence is located in the Kunteyi playa in the west of the Qaidam Basin, Western China (Bingxiao \& Kejun, 1986). Antarcticite has also been found in stratified fresh to salt water columns in onshore "blue holes" on North Andros Island (Bahamas) (Eckstein et al., 1994). In all these places antarcticite forms in hypersaline lakes by extreme evaporation, and is associated with halite and gypsum. In Atacama this calcium chloride mineral was found as pure curly white crystals growing on a fine-grained interbedded layer surfacing a cave wall in the Arco de la Paciencia Cave. The genetic mechanism that has allowed the formation of this mineral in the karst environment is far more complex than the extreme evaporation of the hypersaline lakes of the other locations. In fact, in this cave antarcticite has not crystallised in evaporated pools, but on a dry cave wall. The mineral seems to have formed starting from capillary water seeping out from the fine-grained sediments, probably following exceptional rain and/ or snow events that occurred some months before its discovery (Fig. 9).

The calcium necessary for the formation of this chloride derives from the gypsum and/or the silicates that typically fill fractures and/or pockets under the salt crusts at the external surface of the Cordillera de la Sal. The water seeping into the cave through joints and more permeable bedding planes (i.e. the silty and sandy sequence interbedded in the salt units of the Paciencia Group) are able to dissolve primary minerals (halides and sulphates) and bring ions into solution. Also important, often-violent flood events dissolve a large amount of elements, but cannot be considered responsible for the slow capillary movement of interstitial fluids necessary for the formation of antarcticite. Seepage, on the other hand, is able to keep the fine sediments filling these pockets or the interbedded layers moist over long periods of time (several months), also thanks to the shielding 

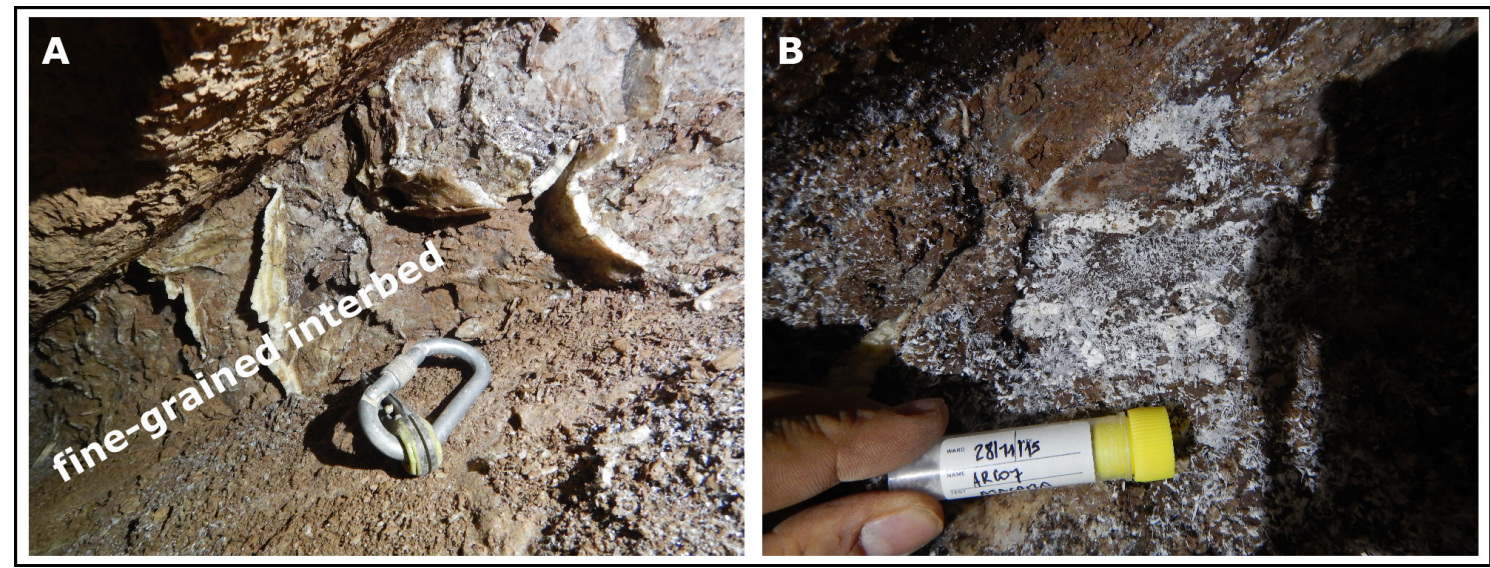

Fig. 9. Field occurrence of Antarcticite in Arco de la Paciencia Cave. A) The fine-grained interbedded layer where the antarcticite curls were found (white dots on the clayey background); B) Detail of the antarcticite crystals (Photos Marco Vattano, La Venta Esplorazioni Geografiche).

capacity of the impermeable salt crust that uniformly covers the entire surface of the Atacama Desert.

These sediment-laden pockets constitute a humid micro-environment in which solubilisation occurs during rain events, and evaporation-deposition during most of the year (Fig. 10A). In the intermediate zone, capillary movement of water follows in a downward direction during rainwater seepage and upward when evaporation prevails. Along the downward pathway the fluids enrich in salts (the calcium chloride salt being among the most soluble ones) until saturation occurs. This cyclic process of solubilisation and precipitation in parts closer to the surface is responsible for the increase in the most soluble salts. Antarcticite is a very hygroscopic substance and its very high solubility inhibits the more abundant sodium chloride to go into solution because of the common-ion effect $(\mathrm{NaCl}$ is ten times less soluble than $\mathrm{CaCl}_{2}$ ). This calcium chloride is also a diagnostic mineral produced by the final evaporation of a neutral brine very depleted in sulfate after the early precipitation of anhydrite (Bridge \& Demicco, 2008). If the proportion of calcium concentration in the solution exceeds that of magnesium, a further loss of water consumes sulfate with the segregation of leonite, and eventually barite, and the resulting solution is enriched in sodium and calcium chloride (Fig. 10B). In general, however, this salt precipitates as an ephemeral mineral phase inside the sediment itself (Fig. 10C) or, in some cases (e.g. following a period of intense precipitation, such as the one occurred at the end of March 2015, eight months before our fieldwork in the Cordillera de la Sal) this calcium chloride-rich fluid can reach the cave walls. The piston-effect of seepage pushed a very small quantity of these enriched fluids to the surface on the ventilated cave walls, and its complete evaporation allowed antarcticite to precipitate as tiny curly white crystals (Fig. 10D).

\section{Anhydrite}

Gypsum, bassanite, and anhydrite have commonly been found in the salt caves of Atacama and at the surface of salt karst areas. In the Cordillera de la Sal, gypsum is widespread at the surface, occurring
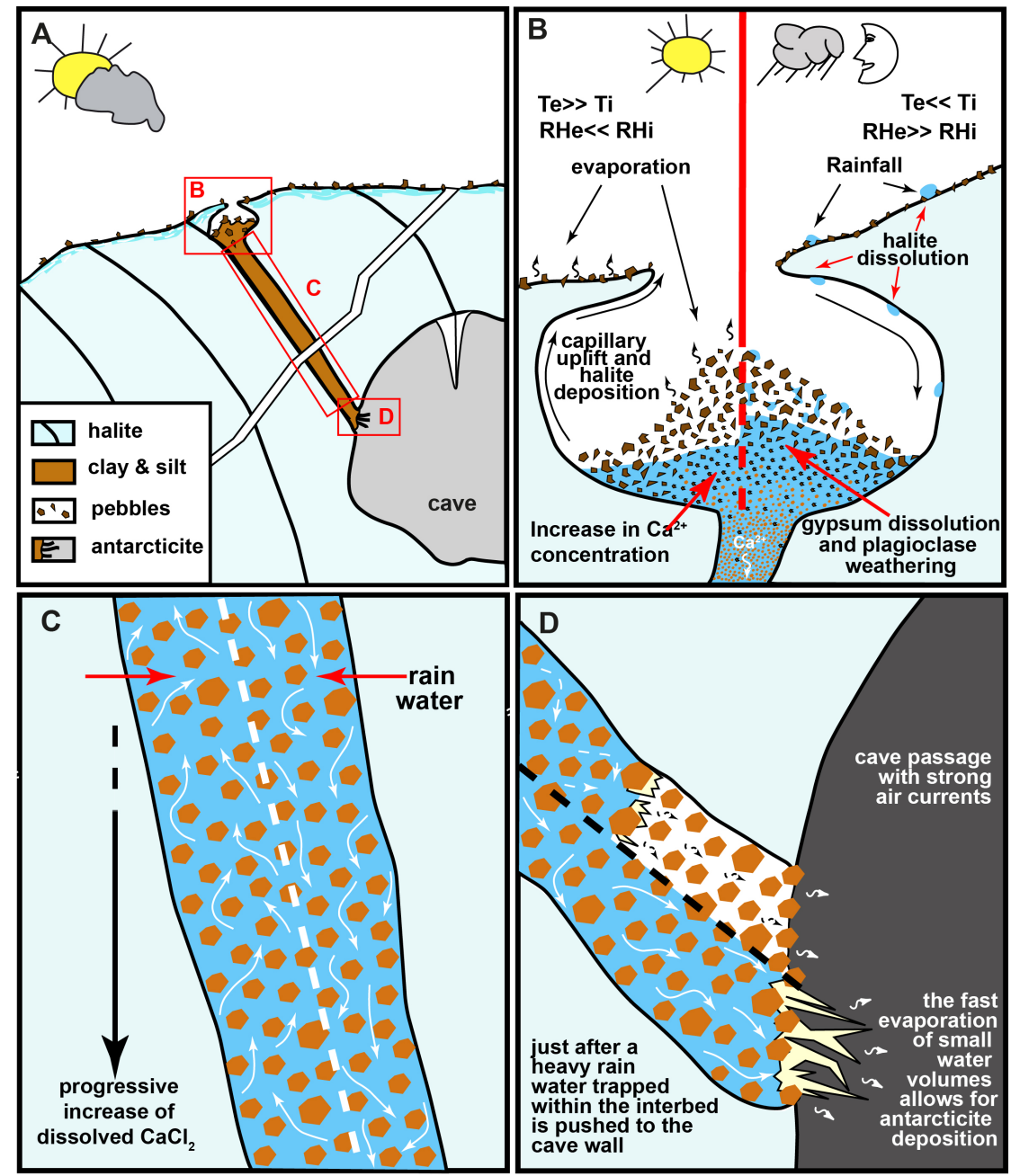

Fig. 10. Conceptual model for the formation of antarcticite in the Atacama caves. A) General view showing the fine-grained interbedded layer, the surface pockets and the underlying cave; B) The cyclic solubilisation-evaporation responsible for the fractional enrichment of the fluids; C) Capillary movement of the waters increasingly enriched in calcium and chloride; D) Formation of antarcticite in the final stages by evaporation in the cave environment. $(\mathrm{Te}=$ external temperature, $\mathrm{Ti}=$ internal temperature, $\mathrm{RHe}=$ external relative humidity, $\mathrm{RHi}=$ internal relative humidity). 
as crystals and in veins several decimetres long (De Waele \& Forti, 2010). The gypsum outcrops are locally named Hoodoos (De Waele \& Forti, 2010) and are only rarely observed inside caves, where anhydrite is by far the most common sulfate mineral. The presence of secondary anhydrite in halite caves has been reported from Mount Sedom (Israel) (Forti \& Buzio, 1985; Frumkin \& Forti, 1997). These previous studies have also demonstrated that the sulfate that precipitates in pools enriched in $\mathrm{NaCl}$ is anhydrite, and not gypsum. In 2015, in the Arco de la Paciencia Cave, a very special occurrence of anhydrite was discovered (Fig. 11). Here, this sulfate outcrops as white powders, filling pockets and fractures in the halite cave walls (Fig. 11A-B). These powders were also found below these deposits, forming half metre high cones or winding traces on the floor (Fig. 11C). Pure anhydrite residues have also been reported in other caves of Atacama, always well above the present cave river thalweg, far out of the flow of waters even during the most extreme flood events. These anhydrite deposits resemble those of gypsum described in caves of Sicily (Italy), New Mexico, Argentina, and Russia (Hill \& Forti, 1997). In all of these cave occurrences mentioned in Hill and Forti, these fine gypsum particles form by different mechanisms, including: 1) biological digestion of guano in presence of fluids enriched in calcium and sulphate; 2) rapid evaporation of small water volumes surfacing on permeable cave walls (cfr. antarcticite); 3) segregation processes following the freezing of waters containing calcium sulphate.
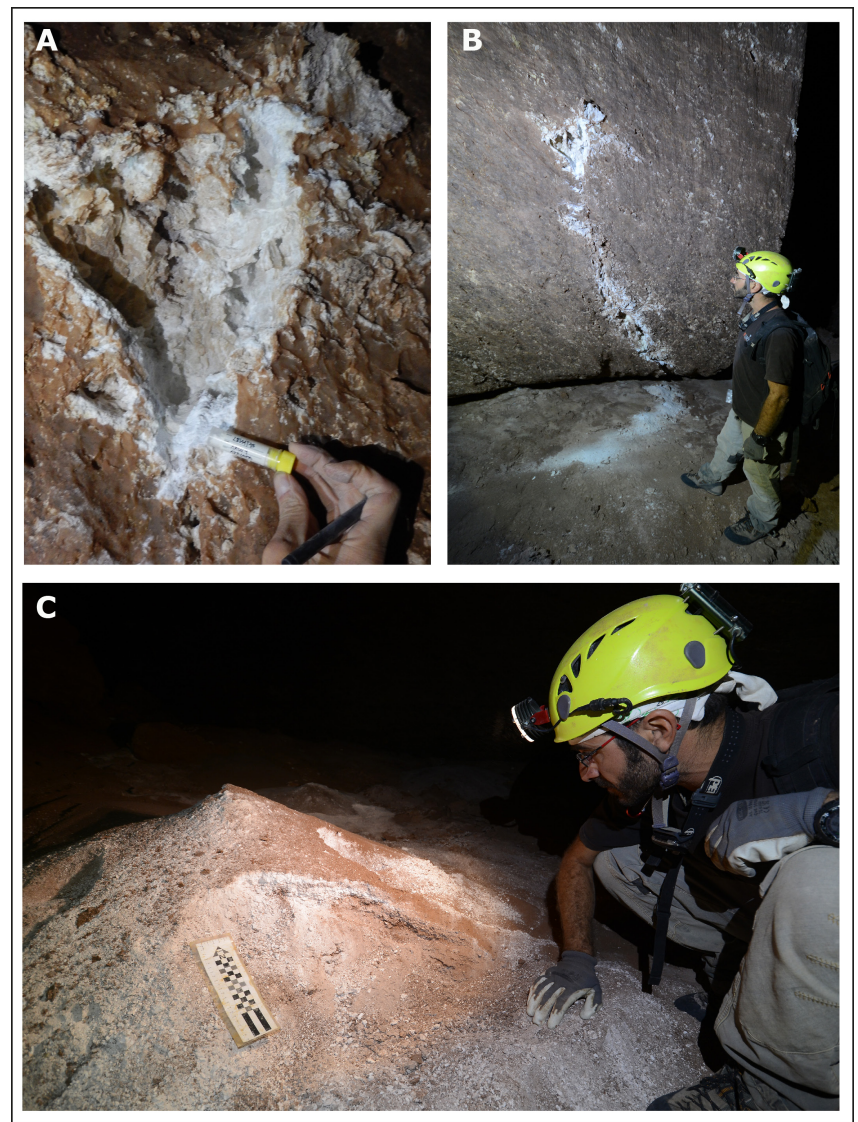

Fig. 11. Anhydrite in Arco de la Paciencia Cave: A) Powdery anhydrite filling a pocket in the cave wall; B) The pocket, a fracture and the underlying deposits of pure white anhydrite powders; C) A half a metre high heap of pure anhydrite on the cave floor (Photos Marco Vattano, La Venta Esplorazioni Geografiche).
However, none of these mechanisms can explain the formation of anhydrite in the halite caves of Atacama. First of all the halite bedrock is not permeable enough (in fact, primary porosity is close to zero), and also freezing in the caves most probably does not occur in this climate. In the Atacama case, anhydrite precipitation can only occur by a fractionated crystallisation starting from a sodium chloride saturated solution with small concentrations of calcium and sulfate through slow evaporation. In this way the forming halite crystals increase their size without taking up impurities, such as small anhydrite crystals. This process cannot explain the small dimension of anhydrite crystals, however, and its powdery appearance instead depends on the very arid atmosphere and the rare rain events. In normal conditions anhydrite would form large crystals similar to those of Liquid Crystal Cave in the Mount Sedom area. During the sporadic rain events water infiltrates into the joints, bedding planes and fractures, bringing into solution calcium and sulfate from the overlying sediments. Penetrating into the halite bedrock through discontinuities, rainwater becomes saturated with respect to sodium chloride very quickly. When this solution reaches the cave voids it rapidly gives rise to the formation of the typical halite stalactites and flowstones. In the case where brine flows through tinier fractures and planes, capillary forces drive the water movement (Fig. 12A). Faster running waters, in fact, would have washed the anhydrite powders easily away, similar to what has occurred for the gypsum powders in New Mexico (Calaforra \& Forti, 1994). Also dripping water would have transformed these residues into solid crusts or cemented material, as has happened in Argentinian caves (Forti et al., 1993). The formation of this anhydrite powder is thus controlled by the quantity of water that infiltrates following every rain episode (Fig. 12B). After every precipitation event the water becomes saturated in sodium chloride during its capillary movement and later this film dries up very slowly, allowing the halite to cover the rock salt walls within the fractures and leaving the remaining fluids increasingly enriched in calcium and sulphate. At the end of this process the brine is broken into isolated droplets which evaporate completely and lead to the precipitation of fine particles of anhydrite (Fig. 12C). This dry anhydrite powder can then move through the tiny fractures driven by gravity (Fig. 12D). Because rainfall is very infrequent in Atacama, and the fact that every single rain event probably forms only very small amounts of anhydrite, the rather large deposits found in Arco de la Paciencia Cave are probably the result of hundreds of precipitation events (and thus thousands of years).

\section{Blödite, darapskite, and leonite}

As in evaporitic closed basins at the surface, it is quite common within Atacama caves to have ephemeral crusts of gypsum and particularly halite covering dry cave lakes. The sudden rainwater inflow during the rare floods forms small water bodies that slowly dehydrate in depressions along the cave passages. These cave pools correspond to closed basins in which 

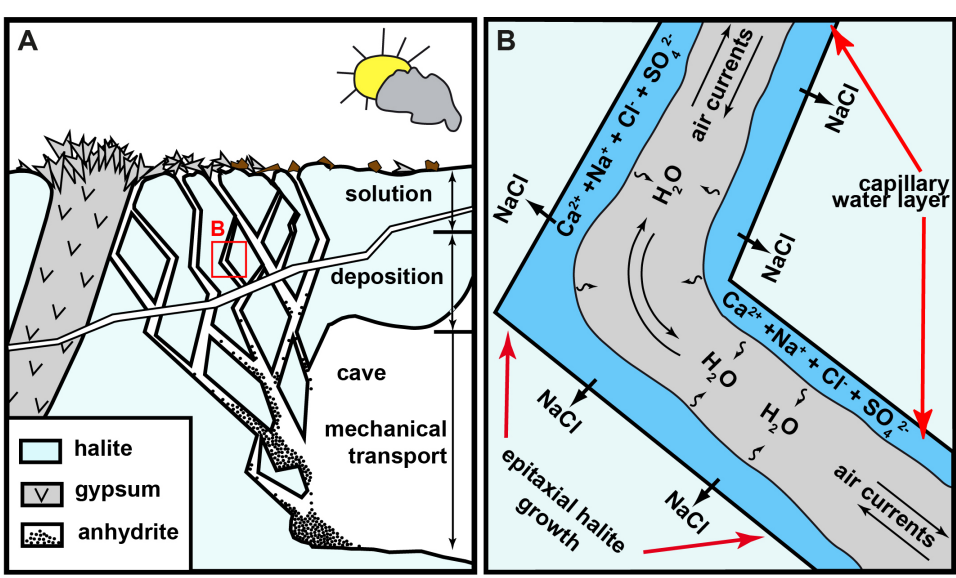

formation of these mineral species (magnesium, potassium, sulphate, nitrates) derive in part from the moist sediments underlying the salt crust, containing epiclastic (delivering the potassium and magnesium) and organic (nitrates and phosphates) materials (Fig. 14A). These last are brought into the cave from the entrances, where birds usually build their nests (guano). The slow evaporation of cave pools first allows halite to precipitate as crusts, rafts, and shelfstones that progressively grow on the borders of the pools (Fig. 14B), forming larger salt crystals on the muddy floor. As the relative salt concentration is increased and some small windows through
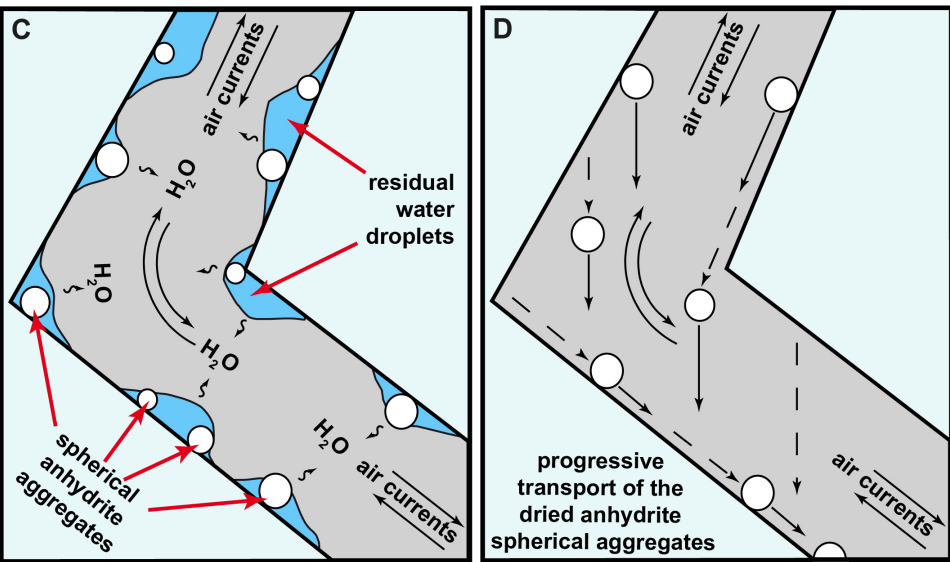

Fig. 12. Conceptual model for the mechanism involved in the deposition of the powders: A) General overview of the fractured halite bedrock; B) Capillary water flow in the fracture after a rain event; $C$ ) Formation of isolated water droplets enriched in anhydrite; D) Gravitational movement of the small pure-anhydrite crystallites.

the brines are concentrated by intense evaporation. The most characteristic mineral paragenesis in these dry lakes is constituted by darapskite, blödite, and leonite, which occur in yellowish crusts well visible in large salt-crusted cave pools in the Cressi cave system (Fig. 13).

Darapskite is widespread in nitrate deposits, filling cavities in saline arid soils, where it is a component of efflorescences and other incrustations. It is a very rare cave mineral and has been reported previously only from a cave in Texas (Hill \& Ewing, 1977). In the sodium chloride crust in the central parts of the pools are still open to the cave atmosphere, the rise of capillary water leads to precipitate a polymineral assemblage containing blödite, leonite and darapskite together with halite to form in the middle of the pool (Fig. 14C). Along segregation pathways, potassium or sodium sulphates are the earliest minerals in the precipitation sequence. In sodium chloride saturated brines at temperature below $25^{\circ} \mathrm{C}$, leonite will not precipitate because blödite deposits first (Jones \& Deocampo, 2005). After the precipitation of the double magnesium salts (blödite and leonite), the proportion of sulfate left in the solution will determine whether the final fluid will allow the formation of darapskite or only of halite. The hydrated sodium nitrate sulfate darapskite, usually unstable below $13.5^{\circ} \mathrm{C}$, tends to appear after leonite when the cave atmosphere dries out, and disappears at temperatures below $7.2^{\circ} \mathrm{C}$ or in presence of moisture.

\section{A potential analogue for Mars subsurface salts}

Several of the secondary minerals found in the caves of the Atacama Desert are postulated to be present also in evaporative environments on Mars (Squyres et al., 2004). Among them, antarcticite is the most interesting because, alongside $\mathrm{Na}$ - and $\mathrm{Mg}$ brines, $\mathrm{CaCl}_{2}$-rich brines are expected in the deep subsurface of Mars, although they might be somewhat Atacama the nitrate is probably supplied by urine and guano, or recycled from cement in the sediments. Blödite, on the other hand, is a much more common mineral in caves, and has been reported from the Mammoth Cave National Park caves (Freeman et al., 1973), Mount Elgon (Kenya) (Bowell et al., 1996), and the Naica caves in Mexico (Badino et al., 2011). Also leonite precipitates during dehydration of lake water from a magnesium and potassium sulfate mixture. It has been already described in caves (Onac et al., 2001; Snow et al., 2014) even though never in association with darapskite and blödite.

In this salt environment where sodium and chloride are considered ubiquitous, short episodes of flooding provide the major input of dissolved calcium into the system, because during the long dry periods this element is removed by calcium sulfate precipitation. The other chemical components necessary for the

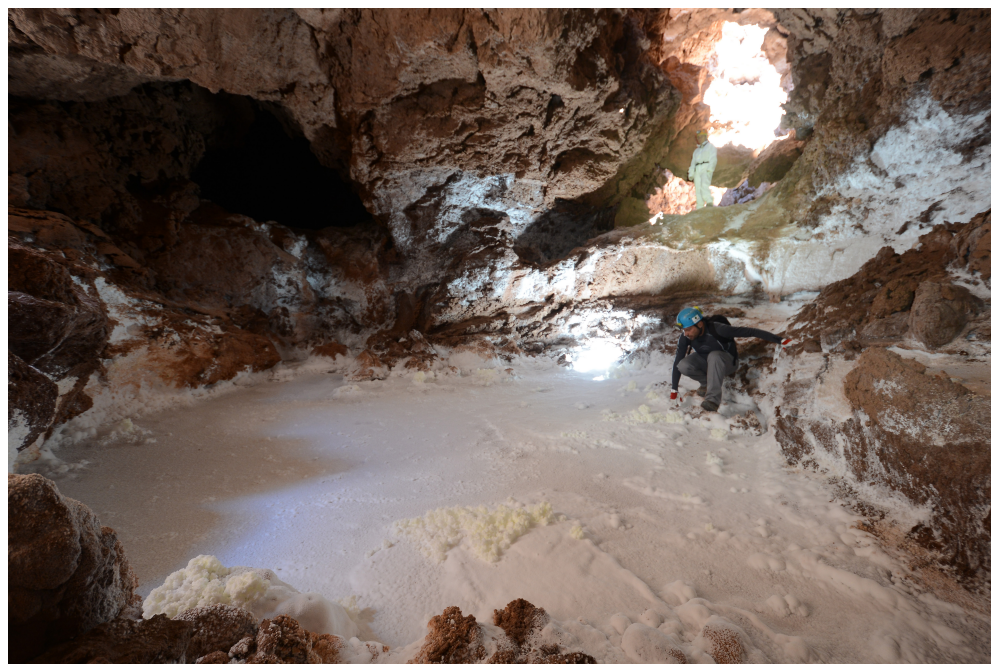

Fig. 13. One of the cave pools in the Cressi cave system, where polymineral aggregates have been found. The yellowish foamy part in the middle of the pool is the area that contains the rich mineral assemblage (Photo Marco Vattano, La Venta Esplorazioni Geografiche). 

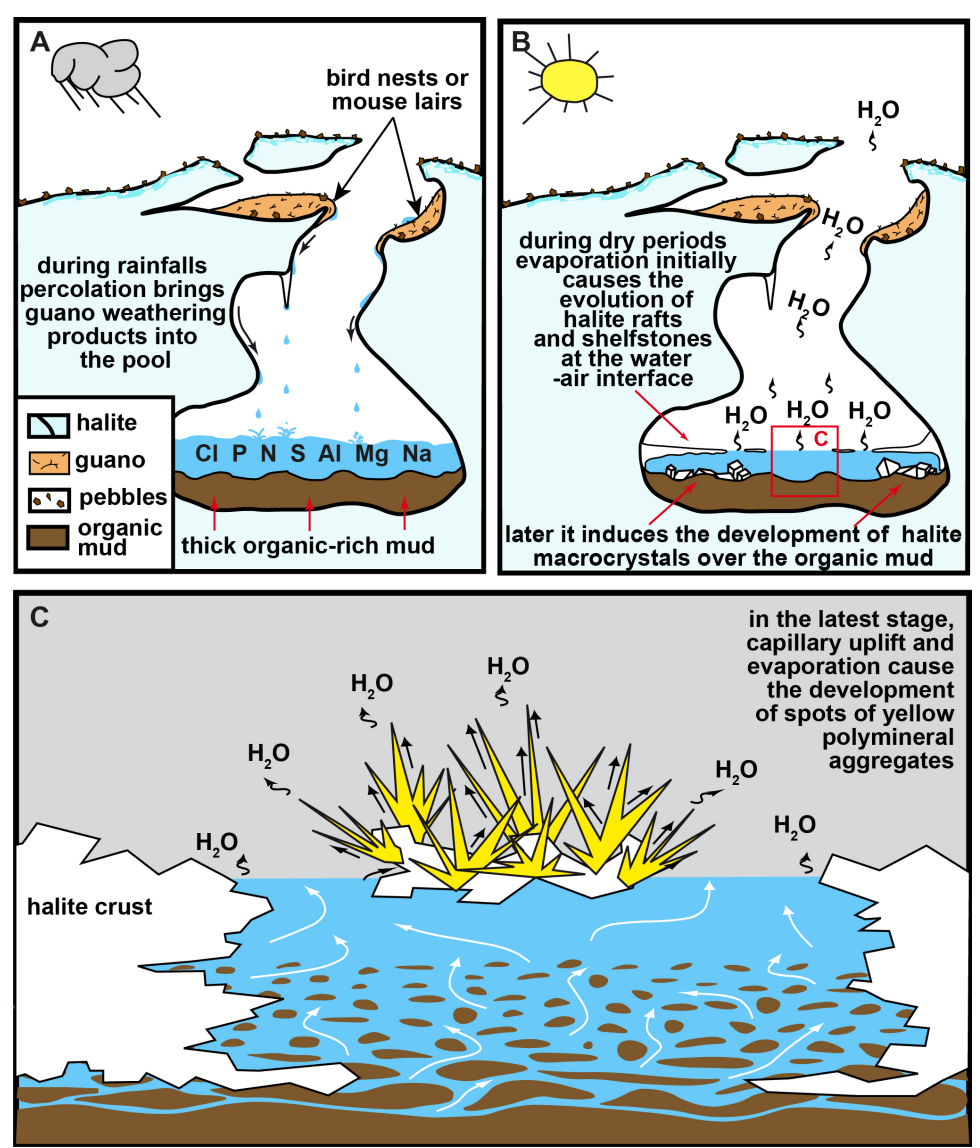

Fig. 14. Formation of the polymineral aggregates in the Cordillera de la Sal caves: A) Rain provides the necessary elements into the cave system and the pools; B) Slow evaporation allows halite to precipitate, especially along the borders of the pools; C) In the final stage islets of polymineral aggregates are formed in the central - still open- part of the pools by slow evaporation and capillary flow of the underlying fluids.

diluted (temperatures permitting) and of variable salt composition (Burt \& Knauth, 2003). In this paper we show that the process of formation of antarcticite is not exclusive of extreme evaporative hypersaline freezing lakes like Don Juan pond in Antarctica as proposed by Burt \& Knauth (2003). Instead, this mineral can form also from differential enrichment of Ca from gypsum or anhydrite by capillary waters along fractures and clay layers in the underground, without any eutectic freeze crystallization. In addition, the presence of an unknown mineral phase, probably a chloride containing both $\mathrm{Ca}$ and $\mathrm{Sr}$, confirms that the formation of minerals with high deliquescence behaviour can easily form in cavities underground in such extremely arid conditions as those of Atacama. These chlorides are highly hygroscopic salts that could result in transient solutions with water activity compatible for life in the Martian subsurface (Davila et al., 2010). A future geomicrobiological study of these minerals in the cave environments of the Atacama Desert could also provide additional hints on how these processes could happen in the deep subsurface even without photosynthetic activity.

Other interesting cave minerals to be considered as potential analogues for the subsurface of Mars are blödite and leonite. On Mars, the interaction of salt brines with basalts (which are the most common substrate on the planet) is expected to have enriched the brine in $\mathrm{Na}$, K, or Mg. Similarly in the Atacama desert caves, sulphates like blödite and leonite are the result of the concentration in these elements sourced by regional volcanic material interlayered with halite deposits. Given the evidence that some evaporitic terrains on Mars have been subject to karst or thermo-karst processes (Baioni et al., 2014; Baioni \& Tramontana, 2016) probably resulting in solutional cavities (Boston, 2004; Baioni et al., 2009), the Atacama caves represent a promising analogue to secondary mineral formations and the potential of life in the Martian subsurface.

\section{CONCLUSIONS}

A total of sixteen secondary minerals have been described as occurring in the salt caves of Atacama, including very rare minerals (atacamite, darapskite, blödite, and leonite) and a new occurrence of antarcticite, a new cave mineral. An unknown calcium-strontium chloride mineral has also been found, but unfortunately its deliquescence and small quantity have not allowed for its detailed classification and description.

Most of the Atacama minerals are highly soluble in water. However, the extremely dry climate of the area permits the formation and persistence of these mineral assemblages. Salt mineral precipitation is controlled by the temperature-dependent solubility of the species in saline water, so that different secondary minerals occur. Processes that drive the crystallization of these phases include the action of thermal fluid-rock interactions and the loss of water through evaporation. Atacamite and aragonite formed from slightly hydrothermal solutions rising along a fault plane in Chulacao Cave.

The other salt minerals in these caves precipitated by evaporative processes during the persistent dry conditions of the Atacama Desert. In fact, the water penetrating along fractures after sporadic rain events leads to the dissolution of primary minerals in the host rock, and the slow evaporation of these saltrich seeping fluids at the cave interface produces speleothems, salt efflorescences and crustal precipitation. Conceptual models for the formation of some of these minerals (i.e., antarcticite, anhydrite, and the blödite-darapskite-leonite association) have been proposed and are unique to this extreme karst environment that is here proposed also as a potential analogue for the study of hygroscopic salts in the Martian subsurface.

\section{ACKNOWLEDGEMENTS}

This research has been made possible thanks to the Integrated Project "Atacama" co-funded by the "Fondazione della Cassa di Risparmio di Bologna" and to La Venta Esplorazioni Geografiche and the Commissione Grotte "Eugenio Boegan" of Trieste that organised the 2015 expedition. Authors are grateful to the director of Valle de la Luna Natural Park for allowing the access to the caves. Special thanks to Kevin Downey (USA) and Elio Padovan (Italy) for their help in finding caves and giving useful information. A special thanks to Prof. Pier Luigi Fabbri of the Centro 
Interdipartimentale Grandi Strumenti (C.I.G.S.) of the University of Modena and Reggio Emilia for the precious help in the ESEM-EDS analyses and Laura Negretti of DISTAV Genova for technical assistance during SEM-EDS analyses. Comments from Michal Filippi, Carol Ann Hill, an anonymous reviewer, and from the editor have been most helpful.

\section{REFERENCES}

Alpers C.N. \& Brimhall G.H., 1988 - Middle Miocene climatic change in the Atacama Desert, northern Chile: Evidence from supergene mineralization at $L a$ Escondida. Geological Society of America Bulletin, 100 (10): 1640-1656.

https://doi.org/10.1130/0016-7606(1988)100 $<1640:$ MMCCIT $>2.3 . \mathrm{CO} ; 2$

Alpers C.N., Jambor J.L. \& Nordstrom D.K. (Eds.), 2000 - Sulfate minerals: crystallography, geochemistry, and environmental significance. Reviews in Mineralogy and Geochemistry, 40: 1-608.

Arriagada C., Cobbold P.R. \& Roperch P., 2006 - Salar de Atacama basin: A record of compressional tectonics in the central Andes since the mid-Cretaceous. Tectonics, 25 (1): TC1009.

https://doi.org/10.1029/2004TC001770

Badino G., Calaforra J. M., Forti P., Garofalo P. \& Sanna L., 2011 - The present day genesis and evolution of cave minerals inside the Ojo de la Reina Cave (Naica Mine, Mexico). International Journal of Speleology, 40 (2): 125-131.

https://doi.org/10.5038/1827-806X.40.2.5

Baioni D., Zupan Hajna N. \& Wezel F.C., 2009 Karst landforms in a Martian evaporitic dome. Acta Carsologica 38 (1): 9-18. https://doi.org/10.3986/ac.v38i1.132

Baioni D., Murana A. \& Tramontana M., 2014 Amazonian thermokarst in Danielson crater, Arabia Terra region, Mars. Planetary and Space Science, 104: 310-317.

https://doi.org/10.1016/j.pss.2014.09.006

Baioni D. \& Tramontana M., 2015 - Evaporite karst in three interior layered deposits in Iani Chaos, Mars. Geomorphology, 245: 15-22.

https://doi.org/10.1016/j.geomorph.2015.05.018

Baioni D. \& Tramontana M., 2016 - Possible karst landforms in two unnamed craters in Tyrrhena Terra, Mars. Planetary and Space Science, 132: 57-65.

https://doi.org/10.1016/j.pss.2016.08.011

Bingxiao L. \& Kejun W., 1986 - Antarcticite found in China. Acta Mineralogica Sinica, 1, 007.

Bobst A.L., Lowenstein T.K., Jordan T.E., Godfrey L.V., Ku T.L. \& Luo S., 2001 - A 106 ka paleoclimate record from drill core of the Salar de Atacama, northern Chile. Palaeogeography, Palaeoclimatology, Palaeoecology, 173: 21-42.

https://doi.org/10.1016/S0031-0182(01)00308-X

Bosák P., Bruthans J., Filippi M., Svoboda T. \& Šmíd J., 1999 - Karst and caves in salt diapirs, SE Zagros Mts., Islamic Republic of Iran. Acta Carsologica, 28 (2): 41-75.

Boschetti T., Cortecci G., Barbieri M. \& Mussi M., 2007 New and past geochemical data on fresh to brine waters of the Salar de Atacama and Andean Altiplano, northern Chile. Geofluids, 7 (1): 33-50.

https://doi.org/10.1111/j.1468-8123.2006.00159.x

Boston P., 2004 - Extraterrestrial caves. In: Gunn, J. (Ed.), Encyclopedia of caves and karst science. Fitzroy Dearborn, New York: 355-357.
Bowell R.J., Warren A. \& Redmond I., 1996 - Formation of cave salts and utilization by elephants in the Mount Elgon region, Kenya. Geological Society, London, Special Publications, 113 (1): 63-79.

https://doi.org/10.1144/GSL.SP.1996.113.01.06

Bridge P.J., 1974 - Guanine and Uricite, two new organic minerals from Peru and Western Australia. Mineralogical Magazine, 39: 889-890.

https://doi.org/10.1180/minmag.1974.039.308.08

Bridge J. \& Demicco V., 2008 - Earth Surface Processes, Landforms and Sediment Deposits. Cambridge University Press, New York, USA.

https://doi.org/10.1017/CBO9780511805516

Bridge P.J., Pryce M.W., Clarke R.M. \& Costello M.B., 1978 - Sampleite from Jingemia Cave, Western Australia. Mineralogical Magazine, 42: 369-371.

https://doi.org/10.1180/minmag.1978.042.323.07

Bruthans J., Asadi N., Filippi M., Vilhelm Z. \& Zare M., 2008 - Erosion rates of salt diapirs surfaces: An important factor for development of morphology of salt diapirs and environmental consequences (Zagros Mts., SE Iran). Environmental Geology, 53 (5): 1091-1098.

Bruthans J., Filippi M., Asadi N., Zare M., Šlechta S. \& Churáčková Z., 2009 - Surficial deposits on salt diapirs (Zagros Mts. and Persian Gulf Platform, Iran): Characterization, evolution, erosion and influence on landscape morphology. Geomorphology, 107: 195-209. https://doi.org/10.1016/j.geomorph.2008.12.006

Bruthans J., Filippi M., Zare M., Churáčková Z., Asadi N., Fuchs M. \& Adamovič J., 2010 - Evolution of salt diapir and karst morphology during the last glacial cycle: effects of sea-level oscillation, diapir and regional uplift, and erosion (Persian Gulf, Iran). Geomorphology, 121: 291-304.

https://doi.org/10.1016/j.geomorph.2010.04.026

Burt D.M. \& Knauth L.P., 2003 - Electrically conducting, Ca-rich brines, rather than water, expected in the Martian subsurface. Journal of Geophysical Research, 108 (E4): 8026.

https://doi.org/10.1029/2002JE001862

Calaforra J.M. \& Forti P., 1994 - Two new types of gypsum speleothems from New Mexico: gypsum trays and gypsum dust. National Speleological Society Bulletin, 56 (1): 32-37.

Clark B.C., 1978 - Implications of abundant hygroscopic minerals in the martian regolith. Icarus, 34: 645-665. https://doi.org/10.1016/0019-1035(78)90052-0

Clarke J.D.A., 2006 - Antiquity of aridity in the Chilean Atacama Desert. Geomorphology, 73: 101-114.

https://doi.org/10.1016/j.geomorph.2005.06.008

Coombs D.S., Alberti A., Armbruster T., Artioli G., Colella C., Galli E., Grice J.D., Liebau F., Mandarino J.A., Minato H., Nichkel E.H., Passaglia E., Peacor D.R., Quartieri S., Rinaldi R., Ross M., Sheppard R.H., Tillmanns E. \& Vezzalini G., 1997 - Recommended nomenclature of zeolite minerals: report of the subcommittee on zeolites of the International Mineralogical Association, commission on new minerals and mineral names. Canadian Mineralogist, 35: 1571-1606.

Davila A.F., Duport L.G., Melchiorri R., Jänchen J., Valea S., de los Rios A. \& Wierzchos J., 2010 - Hygroscopic salts and the potential for life on Mars. Astrobiology, 10 (6): 617-628.

https://doi.org/10.1089/ast.2009.0421

Davila A.F., Hawes I., Ascaso C. \& Wierzchos J., 2013 - Salt deliquescence drives photosynthesis in the hyperarid Atacama Desert. Environmental Microbiology reports, 5 (4): 583-587.

https://doi.org/10.1111/1758-2229.12050 
De Waele J. \& Forti P., 2010 - Salt rims and blisters: peculiar and ephemeral formations in the Atacama desert (Chile). Zeitschrift für Geomorphologie, 54, suppl. 2: 51-67.

De Waele J., Forti P., Picotti V., Galli E., Rossi A., Brook G., Zini L. \& Cucchi F., 2009a - Cave deposits in Cordillera de la Sal (Atacama, Chile). In: Rossi P.L. (Editor), Geological constraints on the onset and evolution of an extreme environment: the Atacama Area, GeoActa, Special Publication 2: 97-111.

De Waele J., Picotti V., Zini L., Cucchi F. \& Forti P., 2009b - Karst phenomena in the Cordillera de la Sal (Atacama, Chile). In: Rossi P.L. (Editor), Geological constraints on the onset and evolution of an extreme environment: the Atacama Area, GeoActa, Special Publication 2: 113-127.

De Waele J., Forti P., Picotti V. \& Zini L., 2009c - Halite macrocrystalline stalactites of the Atacama caves (Chile). Proceedings $\mathrm{XV}^{\text {th }}$ International Congress of Speleology, Kerrville (Texas), 1: 296-299.

De Waele J., Picotti V., Forti P., Brook G., Cucchi F. \& Zini L., 2009d - Age of caves in the Cordillera de la Sal (Atacama, Chile). Proceedings $15^{\text {th }}$ International Congress of Speleology, Kerrville (Texas), 2: 825-830.

DiRuggiero J., Wierzchos J., Robinson C.K., Souterre T., Ravel J., Artieda O., Souza-Egipsy V. \& Ascaso C., 2013 - Microbial colonisation of chasmoendolithic habitats in the hyper-arid zone of the Atacama Desert. Biogeosciences, 10: 2439-2450.

https://doi.org/10.5194/bg-10-2439-2013

Dunai T.J., Lopez G.A.G. \& Juez-Larre J., 2005 Oligocene-Miocene age of aridity in the Atacama Desert revealed by exposure dating of erosion-sensitive landforms. Geology, 33 (4): 321-324. https://doi.org/10.1130/G21184.1

Dunning C.E. \& Cooper J.F., 1969 - A second occurrence of antarcticite from Bristol Dry Lake, California. American Mineralogist, 54: 1018-1025.

Eckstein Y., Manecki M., Matyjasik M. \& Rosenthal E., 1994 - Hydrochemical stratification and processes in three "blue holes" on North Andros Island, Bahamas. Geological Society of America. Prog. and Abs., 26, 360.

Evenstar L.A., Hartley A.J., Archer S.G. \& Neilson J.E., 2016 - Climatic and halokinetic controls on alluvial-lacustrine sedimentation during compressional deformation, Andean forearc, northern Chile. Basin Research, 28: 634-657.

https://doi.org/10.1111/bre.12124

Ericksen G.E.,1983 - The Chilean Nitrate Deposits: The origin of the Chilean nitrate deposits, which contain a unique group of saline minerals, has provoked lively discussion for more than 100 years. American Scientist, 71: 366-374.

Filippi M., Bruthans J., Palatinus L., Zare M. \& Asadi N., 2011 - Secondary halite deposits in the Iranian salt karst: general description and origin. International Journal of Speleology, 40 (2): 141-162. https://doi.org/10.5038/1827-806X.40.2.7

Forti P. \& Buzio A., 1985 - Una nuova scoperta nelle grotte di Monte Sedom (Israele): le eccentriche di anidrite. Notiziario di Mineralogia e Paleontologia, 46: 11-16.

Forti P., Costa G., Outes V., Re G. \& Barredo S., 1993 Two peculiar karst forms of the gypsum outcrop between Zapala and Las Lajas (Neuquen, Argentina). In: Proceedings of the $11^{\text {th }}$ International Congress of Speleology, Bejing, China: 54-56.

Forti P., Galli E. \& Rossi A., 2004 - Secondary minerals in the caves of Cuatro Ciénegas. In: Badino G., Bernabei T., De Vivo A., Giulivo I. \& Savino G. (eds). Under the desert: the mysterious waters of Cuatro Ciénegas. Tintoretto, Treviso, 228-234.
Freeman J.P., Smith G.L., Poulson T.L., Watson P.J. \& White W.B., 1973 - Lee Cave, Mammoth Cave National Park, Kentucky. National Speleological Society Bulletin, 35: 109-125.

Frumkin A., 1994 - Hydrology and denudation rates of halite karst. Journal of Hydrology, 162: 171-189. https://doi.org/10.1016/0022-1694(94)90010-8

Frumkin A., 1998 - Salt cave cross-sections and their paleoenvironmental implications. Geomorphology, 23: 183-191.

https://doi.org/10.1016/S0169-555X(98)00002-6

Frumkin A. \& Ford D.C., 1995 - Rapid Entrenchment of Stream Profiles in the Salt Caves of Mount Sedom, Israel. Earth Surface Processes and Landforms, 20 (2): 139-152.

https://doi.org/10.1002/esp.3290200205

Frumkin A. \& Forti P., 1997 - Liquid Crystal Cave, Israel. In: Hill C. \& Forti P. (Eds.), Cave minerals of the world. Huntsville, National Speleological Society: 319-322.

Frumkin A., Magaritz M., Carmi I. \& Zak I., 1991 - The Holocene climatic record of the salt caves of Mount Sedom, Israel. The Holocene, 1 (3): 191-200.

Fryer S., 2005 - Halite caves of the Atacama. National Speleological Society News, 63 (11): 4-19.

Gottardi G. \& Galli E. (Eds.), 1985 - Natural zeolites. Springer Verlag. Berlin.

Hecht M.H., Kounaves S.P., Quinn R.C., West S.J., Young S.M.M., Ming D.W., Catling D.C., Clark B.C., Boynton W.V., Hoffman J., De Flores L.P., Gospodinova K., Kapit J. \& Smith P.H., 2009 - Detection of perchlorate and the soluble chemistry of martian soil at the Phoenix lander site. Science, 325: 64-67.

https://doi.org/10.1126/science.1172466

Hartley A.J., Chong G., Houston J. \& Mather A.E., 2005 - 150 million years of climatic stability: evidence from the Atacama Desert, northern Chile. Journal of the Geological Society of London, 162: 421-424. https://doi.org/10.1144/0016-764904-071

Hill C.A. \& Ewing R.C., 1977 - Darapskite, $\mathrm{Na}_{3}\left(\mathrm{NO}_{3}\right)$ $\left(\mathrm{SO}_{4}\right) \cdot \mathrm{H}_{2} \mathrm{O}$, a new occurrence, in Texas. Mineralogical Magazine, 41 (320): 548-550. https://doi.org/10.1180/minmag. 1977.041.320.26

Hill C.A. \& Forti P., 1997 - Cave minerals of the world. National Speleological Society, Huntsville, AL, 464 p

Houston J. \& Hartley A. J., 2003 - The central Andean west-slope rainshadow and its potential contribution to the origin of hyper-aridity in the Atacama Desert. International Journal of Climatology, 23 (12): 14531464.

https://doi.org/10.1002/joc.938

Jones B.F. \& Deocampo D.M. 2005 - Geochemistry of saline lakes. In: Drever J.I. (Ed.), Surface and ground water, weathering, and soils. Treatise on Geochemistry, 5: 393-424.

https://doi.org/10.1016/B0-08-043751-6/05083-0

Lowenstein T.K., Hein M.C., Bobst A.L., Jordan T.E., Ku T.L. \& Luo S., 2003 - An assessment of stratigraphic completeness in climate-sensitive closed-basin lake sediments: Salar de Atacama, Chile. Journal of Sedimentary Research, 73: 91-104. https://doi.org/10.1306/061002730091

Mason B. \& Sand L.B., 1960 - Clinoptilolite from Patagonia. The relationship between clinoptilolite and heulandite. American Mineralogist, 45: 341-350.

Morales M.S., Christie D.A., Villalba R., Argollo J., Pacajes J., Silva J.S., Alvarez C.A., Llancabure J.C. \& Soliz Gamboa C.C., 2012 - Precipitation changes in the South American Altiplano since 1300AD reconstructed by tree-rings. Climate of the Past, 8: 653-666.

https://doi.org/10.5194/cp-8-653-2012 
Mpodozis C., Arriagada C., Basso M., Roperch P., Cobbold P. \& Reich M., 2005 - Late mesozoic to paleogene stratigraphy of the Salar de Atacama Basin, Antofagasta, Northern Chile: Implications for the tectonic evolution of the Central Andes. Tectonophysics, 399 (1-4): 125-154.

https://doi.org/10.1016/j.tecto.2004.12.019

Onac B.P., 1996 - Mineralogy of speleothems from caves in the Padurea Craiului Mountains (Romania), and their palaeoclimatic significance. Cave and Karst Science, 23 (3): 109-124.

Onac B.P., White W.B. \& Viehmann I., 2001 - Leonite $\left[\mathrm{K}_{2} \mathrm{Mg}\left(\mathrm{SO}_{4}\right)_{2} \cdot 4 \mathrm{H}_{2} \mathrm{O}\right]$, konyaite $\left[\mathrm{Na}_{2} \mathrm{Mg}(\mathrm{SO})_{4} \cdot 5 \mathrm{H}_{2} \mathrm{O}\right]$ and syngenite $\left[\mathrm{K}_{2} \mathrm{Ca}\left(\mathrm{SO}_{4}\right)_{2} \cdot \mathrm{H}_{2} \mathrm{O}\right]$ from Tăuşoare Cave, Rodnei Mts, Romania. Mineralogical Magazine, 65: 1-7. https://doi.org/10.1180/002646101550154

Ortlieb L., 1994 - Major Historical Rainfalls in Central Chile and the Chronology of ENSO Events during the $16^{\text {th }}-19^{\text {th }}$-Centuries. Revista Chilena De Historia Natural, 67 (4): 463-485.

Padovan E., 2015 - L'esplorazione delle grotte nella Cordillera de la Sal Salar de Atacama - Chile. Atti XXII Congresso Nazionale di Speleologia, Auletta-Pertosa, Italy: 617-629.

Reich M. 2008 - Atacamite formation by deep saline waters in copper deposits from the Atacama Desert, Chile: Evidence from fluid inclusions, groundwater geochemistry, TEM, and ${ }^{36} \mathrm{Cl}$ data. Mineralium Deposita, 43: 663-675.

https://doi.org/10.1007/s00126-008-0184-4

Salomon J.-N., 1995 - Le Chili. Pays des karsts extrèmes. Karstologia, 24: 52-56.

Sesiano J., 1998 - Phénomènes karstiques en zone aride. Le désert d'Atacama, au Nord du Chili. Hypogées "Les Boueux", 64: 48-52.

Sesiano J., 2006 - Evolution actuelle des phénomènes karstiques dans la Cordillera de la Sal (Atacama, Nord Chili). Karstologia, 47: 49-54.
Sesiano, J., 2007 - Etude de deux grottes dans le sel au nord $d u$ Chili. Actes $12^{\circ}$ Congrès national suisse de Spéléologie, Vallée de Joux (Switzerland), 15-17 September 2007: 121-128.

Sesiano J., 2009 - Nouvelles observations sur un massif de selgemme dans la Cordillera de la Sal, désert d'Atacama, nord du Chili. Archives des Sciences Génève, 62: 71-86.

Sillitoe R.H. \& McKee E.H., 1996 - Age of supergene oxidation and enrichment in the Chilean porphyry copper province. Economic Geology, 91 (1): 164-179. https://doi.org/10.2113/gsecongeo.91.1.164

Snow M. R., Pring A. \& Allen N., 2014 - Minerals of the Wooltana Cave, Flinders Ranges, South Australia. Transactions of the Royal Society of South Australia, 138 (2): 214-230. https://doi.org/10.1080/03721426.2014.11649009

Squyres S. W., Grotzinger J. P., Arvidson R. E., Bell J. F., Calvin W., Christensen P. R. \& Johnson J. R., 2004 - In situ evidence for an ancient aqueous environment at Meridiani Planum, Mars. Science, 306 (5702): 1709-1714. https://doi.org/10.1126/science.1104559

Torii T. \& Ossaka J., 1965 - Antarcticite: a new mineral, calcium chloride hydrate, discovered in Antarctica. Science, 149: 975-977.

https://doi.org/10.1126/science.149.3687.975

Wierzchos J., Ascaso C. \& McKay C.P., 2006 - Endolithic cyanobacteria in halite rocks from the hyperarid core of the Atacama Desert. Astrobiology, 6: 415-422. https://doi.org/10.1089/ast.2006.6.415

Wilkes E. \& Görler K., 1994 - Sedimentary and structural evolution of the Salar de Atacama Depression. In: Reutter K.-J., Scheuber E. \& Wigger P.J. (Eds.), Tectonics of the southern central Andes. Structure and evolution of an active continental margin. Berlin, Springer-Verlag: 171-188.

https://doi.org/10.1007/978-3-642-77353-2 12 